\title{
Plankton distribution associated with frontal zones in the vicinity of the Pribilof Islands
}

\author{
Mikhail V. Flint ${ }^{\mathrm{a}, \mathrm{c}, *}$, Irina N. Sukhanova ${ }^{\mathrm{a}}$, Alexander I. Kopylov ${ }^{\mathrm{b}}$, \\ Sergei G. Poyarkov ${ }^{\mathrm{a}}$, Terry E. Whitledge \\ ${ }^{a}$ P.P. Shirshov Institute of Oceanology, Russian Academy of Sciences, Nakhimovski pr. 36, Moscow 117851, Russia \\ ${ }^{\mathrm{b}}$ Institute for Biology of Inland Waters, Russian Academy of Sciences, Borok, Nekouz, Yaroslavl 152742, Russia \\ ${ }^{\mathrm{c}}$ Institute of Marine Sciences, School of Fisheries and Ocean Sciences, University of Alaska Fairbanks, Fairbanks, AK 99775-7220, USA
}

\begin{abstract}
We studied the effect of four types of fronts, the coastal front, the middle front, the shelf partition front and the shelf break front on the quantitative distribution and the composition of plankton communities in the Pribilof area of the eastern Bering Sea shelf in late spring and summer of 1993 and 1994. The coastal fronts near St. Paul and St. George Islands and the coastal domains encircled by the fronts featured specific taxonomic composition of planktonic algae, high abundance and production of phytoplankton, as well as large numbers of heterotrophic nanoplankton. The coastal fronts also were characterized by high values of total mesozooplankton biomass, high concentrations of Calanus marshallae, as well as relatively high abundances of Parasagitta setosa and Euphausiacea compared to surrounding shelf waters. We hypothesize that wind-induced erosion of a weak thermocline in the inner part of the coastal front as well as transfrontal water exchange in subthermocline layers result in nutrient enrichment of the euphotic layer in the coastal fronts and coastal domains in summer time. This leads to prolonged high primary production and high phytoplankton biomass. In this paper a new type of front - the shelf partition front located $45-55 \mathrm{~km}$ to the north-east off St. Paul Island - is described, which is assumed to be formed by the flux of oceanic domain waters onto the shelf. This front features a high abundance of phytoplankton and a high level of primary production compared to the adjacent middle shelf. Near the southwestern periphery of the front a mesozooplankton peak occurred, composed of $C$. marshallae, with biomass in the subthermocline layer, reaching values typical for the shelf break front and the highest for the area. High abundance of phyto- and zooplankton as well as heterotrophic nanoplankton and elevated primary production were most often observed in the area adjacent to the shelf break front at its oceanic side. The phyto- and mesozooplankton peaks here were formed by oceanic community species. The summer levels of phytoplankton numbers, biomass and primary production in the shelf break frontal area were similar to those reported for the outer and middle shelf during the spring bloom and the coastal domains and coastal fronts in summer. In the environment with a narrow shelf to the south of St. George Island, the mesozooplankton peak was observed at the inner side of the shelf break front as close as $20 \mathrm{~km}$ from the island shore and was comprised of a "mixed" community of shelf and oceanic species. The biomass in the peak reached the highest values for the Pribilof area at $2.5 \mathrm{~g}$ mean wet weight $\mathrm{m}^{-3}$ in the $0-100 \mathrm{~m}$ layer. Details of the taxonomic composition and the numbers and production of phytoplankton hint at the similarity of processes that affect the phytoplankton summer community in the coastal domains of the islands, at the coastal fronts, and at the oceanic side of the shelf break front. The middle front was the only one that had no effect on plankton composition or its quantitative characteristics in June and July. Location of a variety of frontal productive
\end{abstract}

\footnotetext{
*Corresponding author. P.P. Shirshov Institute of Oceanology, Russian Academy of Sciences, Nakhimovski pr. 36, Moscow 117851, Russia. Tel.: + 1-95-124-8515; fax: + 1-94-124-5983.

E-mail addresses: m_flint@orc.ru (M.V. Flint).
} 
areas within $100 \mathrm{~km}$ of the Pribilof Islands creates favorable foraging habitat for higher trophic level organisms, including sea birds and marine mammals, populating the islands.

(C) 2002 Elsevier Science Ltd. All rights reserved.

\section{Introduction}

The Pribilof area is distinguished by high biological productivity and abundance of various components of the marine ecosystem, which are noticeable even compared to the highly productive eastern shelf of the Bering Sea. The available data show this for phytoplankton (Sukhanova et al., 1999), zooplankton (Motoda and Minoda, 1974), bottom invertebrates (Ivanov, 1964; MacIntosh and Somerton, 1981), demersal and bottom fish (Onoda et al., 1986; Traynor and Smith, 1996; Brodeur et al., 1999), sea birds and mammals (Hickey and Craighead, 1977; Sowls et al., 1978; York, 1987). Based on the known influence of oceanographic fronts on pelagic ecosystems (Fedorov, 1983; Le Fevre, 1986; Flint and Kolosova, 1990; Daly and Smith, 1993; Franks and Chen, 1996), we hypothesize that the productivity may be largely due to the existence of various types of fronts in a relatively small area around the islands. The map of frontal locations in the Pribilof area, based on a compilation of literary sources (Schumacher et al., 1979; Kinder and Schumacher, 1981; Kinder et al., 1983; Coachman, 1986; Schneider et al., 1990; Brodeur et al., 1997), as well as on our own data (Flint et al., 1994, 1996; Poyarkov, 2000), is shown in Fig. 1.

Out of the variety of oceanographic fronts in the Pribilof area, only the coastal front has been studied thoroughly enough to reveal its influence on plankton and juvenile fish distribution as well as its importance as a forage area for higher trophic level organisms (Kinder et al., 1983; Schneider et al., 1990; Coyle and Cooney, 1993; Decker and Hunt, 1996; Brodeur et al., 1997). It has been shown that the coastal front may contain relatively high concentrations of chlorophyll, elevated abundance of euphausiids, and age- 0 walleye pollock. Aggregations of sea birds, observed in some cases in the frontal area, hint that the front is an attractive forage ground for

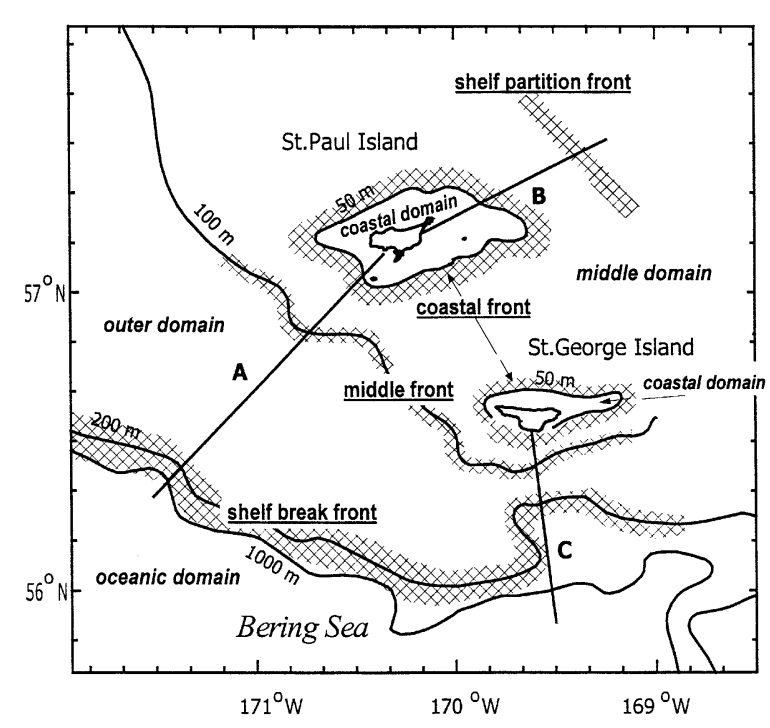

Fig. 1. Oceanographic fronts and domains in the Pribilof area. (A-C) Sampling transects around the Pribilof Islands.

species that feed on large zooplankton and small fish.

In this study we examine the influence of all types of fronts found in the Pribilof area on the quantitative distributions of a broad variety of plankton organisms: phyto- and bacterioplankton, planktonic nanoheterotrophs and mesozooplankton in the summer time when highly productive sites are especially important for sea birds and marine mammals breeding on the islands. We consider not only total numbers and biomass of the surveyed plankton components, but also numbers and biomass of the most abundant and key species of phyto- and zooplankton.

We propose that in the Pribilof area in the summer time oceanographic fronts of various types can be identified as areas of increased numbers, biomass and productivity of various components of plankton that maintain a relative spatial stability. Some of the fronts may be the 
borders in distributions of species with specific ecological preferences.

\section{Materials and methods}

Samples were collected on transects in the vicinity of St. Paul and St. George islands in the late spring and summer of 1993 and 1994 (Fig. 1). In 1993 transect A was occupied on May 27, June 2, 11, and 23, and July 25. Only the transect on June 11 crossed the continental slope area and the shelf break front, while the others only reached the middle domain and the middle front. Transect $\mathrm{B}$ was occupied on July 3, transect C was occupied on July 23. In 1994 transect A was done on June 9 and July 19, transect B was done on June 15 and July 28, transect C was occupied on June 13. Hydrographic stations were located 2-10 km apart along these transects while hydrochemical and biological sampling was largely done with $8-20 \mathrm{~km}$ spacing. The closest spacing of stations was in frontal areas. Phytoplankton, bacterioplankton and heterotrophic nanoplankton were sampled with 5-1 Niskin bottles from 7 depths in the upper mixed layer, thermocline and subthermocline layers down to $200 \mathrm{~m}$.

Phytoplankton samples (1.5-2.01) were concentrated to a volume $40-60 \mathrm{ml}$ with a reverse filtration technique under a pressure of $3 \mathrm{kPa}$ using a $1-\mu \mathrm{m}$ nucleopore screen. The samples were processed without preliminary fixation in order to avoid loss of small readily lysable cells (Sukhanova, 1983). Phytoplankton was identified and counted under a luminescent microscope at $\times 400$ and $\times 200$ magnification. A Nojeotte $(0.08 \mathrm{ml})$ counting chamber was used for smaller and abundant forms while less abundant and large-size cells were counted in a Nauman $(0.5 \mathrm{ml})$ chamber. All phytoplankton cells in the chambers (not less than 200) were measured and the wet biomass (biovolume) was calculated using appropriate geometrical formulas.

Bacterioplankton and heterotrophic nanoplankton counts in 1994 were done by epifluorescent microscopy. Samples for bacteria and heterotrophic nanoplankton counts were preserved with glutaraldehyde ( $1 \%$ final concentration). Bacterial cells were stained with DAPI and then filtered onto $0.2-\mu \mathrm{m}$ pore-size dark nucleopore membranes using a vacuum of $<100 \mathrm{~mm} \mathrm{Hg}$ (Porter and Feig, 1980). Not less than 400 cells were counted in each sample. Samples for heterotrophic nanoplankton quantification were filtered onto $0.4-\mu \mathrm{m}$ pore-size membranes and stained with Primulin (Caron, 1983). On each filter $\geqslant 50$ cells were counted.

In 1994 measurements of phytoplankton primary production by the ${ }^{14} \mathrm{C}$ method (Sorokin, 1973) were carried out using samples collected at $0.5 \mathrm{~m}$ depth. Samples were incubated on the deck for $4-8 \mathrm{~h}$ in conditions of natural light and ambient temperature.

Zooplankton samples were collected with vertical stratified tows of a $0.1-\mathrm{m}^{2}$ mouth square Juday net having a $220-\mu \mathrm{m}$ mesh size. Over the shelf, samples were taken from the layers above and below the thermocline. Over the shelf break and in the oceanic domain, the following layers were also sampled: from 100 to $200 \mathrm{~m}$ (or bottom) and 200 to $500 \mathrm{~m}$. Samples were preserved in $4 \%$ neutral formaldehyde. Zooplankton organisms were counted and measured under a dissecting microscope. Not less than 30 individuals of each taxa or copepodite stage of copepods were counted and measured in aliquots. Rare organisms were counted in the entire sample. Zooplankton wet biomass (biovolume) was calculated from specific length - weight relationships (Gruzov and Alekseeva, 1971) or specific body length/shapebiovolume regressions (Chislenko, 1968). Because of difficulties in identification of Neocalanus plumchrus and $N$. Alemingeri in bulk material that included copepodids beginning from stage III of both species, they were counted together and referred to as $N$. plumchrus $(+N$. flemingeri).

The type of nets used cannot provide quantitative data on of Euphausiacea and large-sized Chaetognatha. Large copepods, to a much smaller extent, also may avoid the Juday net. To reduce copepod avoidance the nets were towed at $0.8 \mathrm{~m} \mathrm{~s}^{-1}$ and the filtering cone was washed with fresh water after each tow to minimize clogging. Therefore, we present the data on the distribution of euphausiids and chaetognaths only in terms of relative values from a comparative viewpoint. The absolute zooplankton biomass as well as the 
biomass of abundant copepod species were determined and shown in figures, but the data are discussed in mainly a comparative context. Over the outer shelf, shelf break and in the oceanic domain the zooplankton biomass below $100 \mathrm{~m}$ did not exceed $10-20 \%$ of the total in the $0-500 \mathrm{~m}$ layer, and we used mean values for $0-100 \mathrm{~m}$ for comparison with shallower domains.

\section{Results}

\subsection{Oceanographic setting}

All of the basic types of fronts that exist on the eastern Bering Sea shelf can be found in the area within $100-110 \mathrm{~km}$ of the Pribilof Islands (Fig. 1). We determined frontal zones as defined by Fedorov (1983) using the criteria of sharp horizontal gradients in the distribution of physical and chemical properties to compare with the mean distribution pattern of the properties. We also used the criteria established for specific types of structural fronts over the eastern Bering Sea shelf (Kinder and Coachman, 1978; Schumacher et al., 1979; Kinder and Schumacher, 1981; Coachman, 1986).

Two major islands in the archipelago, St. Paul and St. George, are surrounded by coastal fronts (Fig. 1), which according to their origin and structure are similar to the inner front found over the depth range of $40-60 \mathrm{~m}$ of the inner shelf (Schumacher et al., 1979). In the late spring, summer and fall the coastal fronts separate the vertically mixed water of the coastal domains from the strictly stratified middle shelf water (Kinder et al., 1983; Schneider et al., 1990; Coyle and Cooney, 1993; Decker and Hunt, 1996; Flint et al., 1994, 1996; Brodeur et al., 1997; Poyarkov and Emelianov, 2000; Poyarkov, 2001). In those seasons coastal fronts are best delineated by temperature distributions (Figs. 2A and B). Water temperature in the coastal domain is generally 2 $4{ }^{\circ} \mathrm{C}$ below that in the surface layer of the surrounding middle domain. Processes in the coastal frontal areas in the summer enable nutrient-rich subthermocline waters from surrounding stratified shelf areas to penetrate into the islands' coastal zones (Flint et al., 1994, 1996; Poyarkov and Emelianov, 2000; Poyarkov, 2001). Therefore, in certain time periods waters of the coastal front and coastal domain are enriched with nutrients compared to surface waters of the middle shelf (Brodeur et al., 1997; Figs. 2C and D).

In the summers of 1993 and 1994 the inner margin of the coastal front to the southwest and the northeast of St. Paul Island was found at 10$13 \mathrm{~km}$ from the shore (Figs. 2A-D). The front was nearly as wide as the coastal domain, $11-13 \mathrm{~km}$ on average. The narrow shelf and the rapid depth increase to the south of St. George Island defined the proximity of the coastal front to the island's shore. The coastal domain here inside the front was as narrow as $4-6 \mathrm{~km}$ (Fig. $2 \mathrm{~F}$ ). The width of the coastal front to the south of St. George Island was about $7 \mathrm{~km}$ (Flint et al., 1996; Poyarkov, 2000).

The middle front (Fig. 1) in the Pribilof area, as in other areas of the eastern Bering Sea shelf (Kinder and Schumacher, 1981; Coachman, 1986), was a transition zone between the strongly stratified middle shelf area and the deeper outer shelf area with a weaker thermocline featuring internal fine structure. To the southwest of St. Paul Island the front was found $45-55 \mathrm{~km}$ away from the shore over the 100-105 $\mathrm{m}$ isobath (Fig. 1). The width of the front was approximately $12-15 \mathrm{~km}$ (Poyarkov, 2000). To the south of St. George Island, due to the steep shelf, the middle front was located less than $13 \mathrm{~km}$ away from the shore. The width of the front was difficult to determine. The spacing between the 100 and $50 \mathrm{~m}$ isobaths, over which the middle and the coastal fronts, respectively, were formed, was less than $10 \mathrm{~km}$. To the south of St. George Island a distinctly two-layered middle domain with a sharp thermocline was not found (Flint et al., 1996).

On transects northeast of St. Paul Island sampled in July 1993 and 1994, a frontal zone, which had not been previously described, was observed at the $68-70 \mathrm{~m}$ isobath in the middle domain. We have named this new front the "shelf partition front" (Fig. 1). This front was pronounced in the distribution of temperature and was especially well identified in the distributions of nutrients and dissolved oxygen (Figs. 2B-D). 

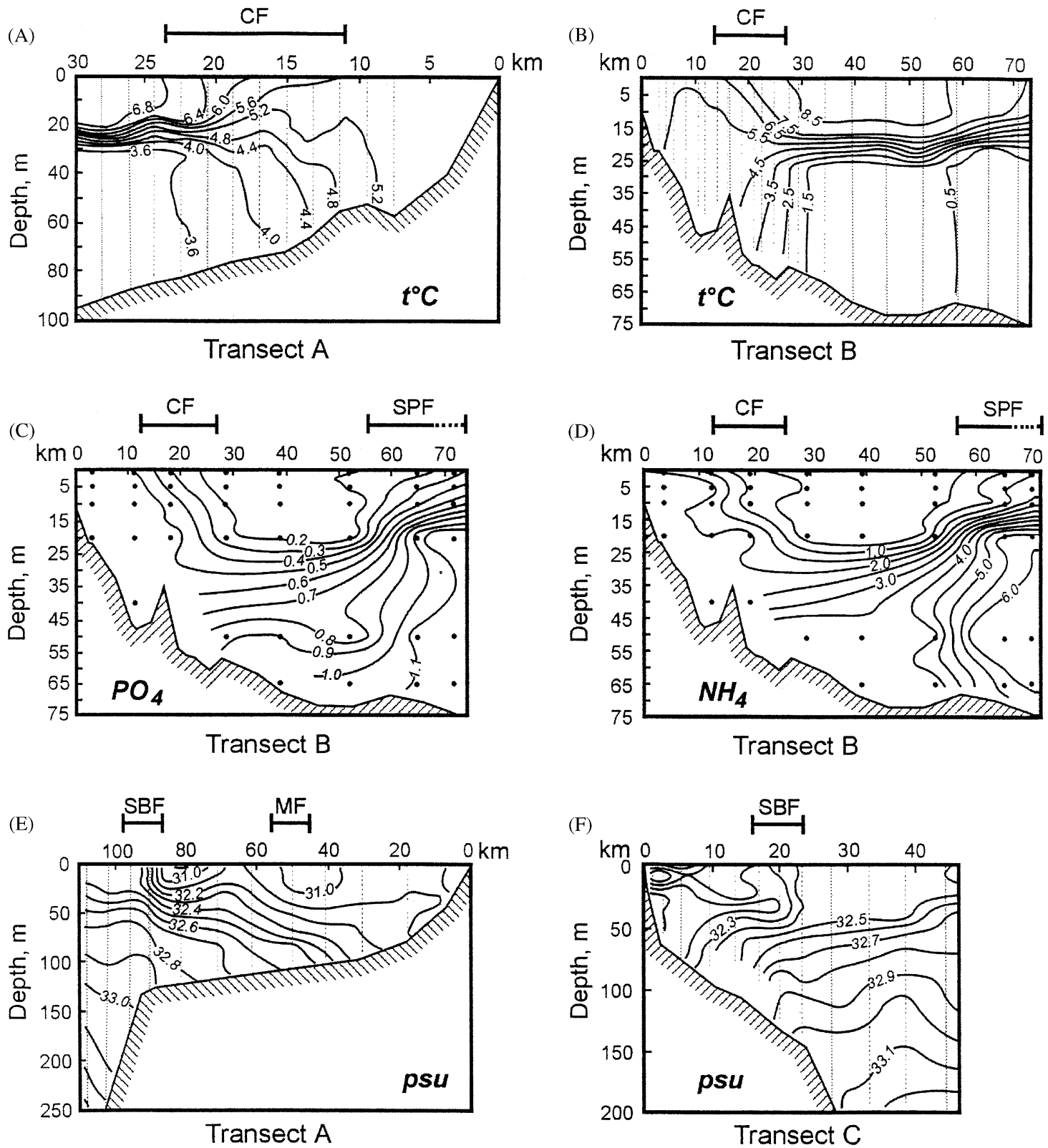

Fig. 2. Examples of temperature, salinity and nutrient distributions that reveal frontal zones of different types. Temperature in transect A, July 1994 (A), and in transect B, July 1994 (B); phosphates (C) and ammonium (D) concentrations in transect B, July 1994; salinity in transect A, June 1993 (E) and in transect C, July 1993 (F). Bars show location of fronts: CF-coastal front; SPF-shelf partition front; $\mathrm{MF}$ - middle front; $\mathrm{SBF}$ - shelf break front.

Surface water in the frontal zone was $0.5-1.0^{\circ} \mathrm{C}$ cooler and enriched in nutrients and dissolved $\mathrm{O}_{2}$ compared to the adjacent middle shelf area to the southwest. In 1993, the southwestern periphery of the shelf partition front was located $40 \mathrm{~km}$ away from the island and the front was about $10 \mathrm{~km}$ wide. In 1994, the shelf partition front was found $15 \mathrm{~km}$ farther to the east. Its southwestern border 
was located $55 \mathrm{~km}$ away from the St. Paul Island shore. The width of the front was not less than $15 \mathrm{~km}$. The transect in July 1994 did not reach the northeast margin of the front (Figs. 2B-D). The origin of the shelf partition front is most likely due to the circulation around the Pribilof Islands, which is related to the onshelf flux of water from the oceanic domain (Stabeno et al., 1999). A wellpronounced branch of the circulation, the southeast flow, was always traced to the north and to the northeast of St. Paul Island. This observation is supported by higher values of salinity (up to $32.2 \mathrm{psu}$ ) and silicates (up to $35 \mu \mathrm{M}$ ) in subthermocline layers on the southwestern side of the front (Flint et al., 1994) as well as some biological indicators discussed below.

The shelf break front (Fig. 1) in the eastern Bering Sea is located over the shelf edge and the upper part of the continental slope over the 130$200 \mathrm{~m}$ isobaths. It is the division between the shelf and the deep basin environments (Kinder and Coachman, 1978; Iverson et al., 1979; Kinder and Schumacher, 1981; Coachman, 1986). Formation of the front is related to the Bering Slope Current and tidal mixing in the shelf break area (Coachman, 1986; Schumacher and Reed, 1993). The shelf break front is most apparent in the distribution of salinity and nutrients (Kinder and Coachman, 1978; Iverson et al., 1979; Coachman, 1986; Whitledge et al., 1986). Processes in the frontal area may cause enrichment of nutrients in the euphotic layer.

The shelf break front to southwest of St. Paul Island was located $90-100 \mathrm{~km}$ away from the shore (Figs. 1 and 2E). The approximate estimate of the frontal zone width was $15-20 \mathrm{~km}$ (Flint et al., 1996; Poyarkov, 2000). Enrichment of the euphotic layer with nutrients was observed in the frontal zone. In June 1994 the concentration of nitrates in the upper mixed layer was $11 \mu \mathrm{M}$. At the same time the concentration of $\mathrm{NO}_{3}$ on the outer shelf was $<6.5 \mu \mathrm{M}$, while the oceanic domain was $<8.2 \mu \mathrm{M}$. The respective values for silicate were $17.5,12.5$, and $15 \mu \mathrm{M}$.

To the south of St. George Island the inner margin of the shelf break front was found 16$20 \mathrm{~km}$ away from the shore and the front was less than $10 \mathrm{~km}$ wide. This is due to the island's proximity to the outer shelf border and the abrupt shelf break to the south of the island. The front, similar to that southwest of St. Paul Island, was most apparent in the distribution of salinity (Fig. 2F) but was far less evident in the distribution of nutrients. In June 1994 frontal features in the distribution of physical properties near the shelf break were much less obvious compared to those in July 1993 (Flint et al., 1996).

\subsection{Plankton}

Phytoplankton in the coastal fronts and coastal domains surrounded by these fronts in the vicinity of St. Paul and St. George Islands (Fig. 1) were dominated by neritic species, whose life cycles include a bottom phase. The dominant species in the phytoplankton of the coastal fronts and coastal domains in the late spring and summer were Chaetoceros socialis, $C$. debilis, $C$. diadema, C. furcellatus, Thalassiosira hyalina, and Fragilariopsis oceanica. These species contributed from $60 \%$ to $90 \%$ of the abundance and from $40 \%$ to $70 \%$ of the biomass in the frontal and coastal phytoplankton community. Beyond the coastal front the numbers dropped one or two orders of magnitude (some of the species are shown in Table 1).

Figs. 3A, B and D show the distribution of phytoplankton numbers along transects between St. Paul Island and the shelf break. The coastal frontal zone and the coastal domain in May and June 1993 and in June 1994 were clearly evident from the higher phytoplankton numbers compared with the surrounding middle shelf. The average cell numbers in the euphotic layer in June 1993 in the coastal domain reached $0.9-1.2 \times 10^{6}$ cells $1^{-1}$, while in the coastal front they were $0.4 \times 10^{6}$ cells $^{-1}$. At the same time in the adjacent middle shelf areas the numbers did not exceed $0.2 \times 10^{6}$ cells $^{-1}$ (Fig. 3A). In June 1994 the phytoplankton abundance in the coastal front

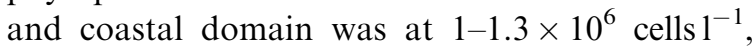
which was twice as high compared to that in the adjacent middle shelf area (Fig. 3B). In July 1994 the pattern was not as strong but still indicated enrichment of the coastal front and coastal domain with phytoplankton (Fig. 3D). The 


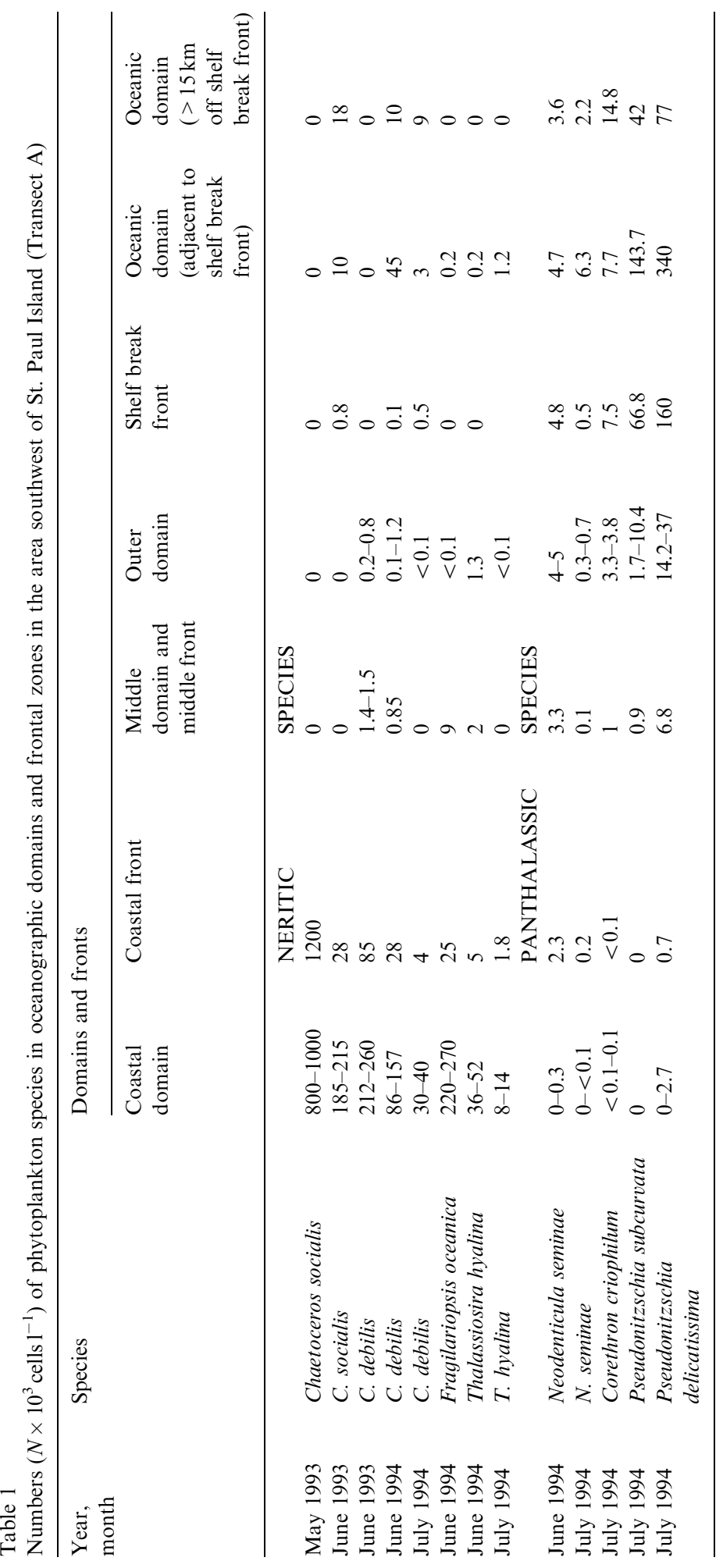



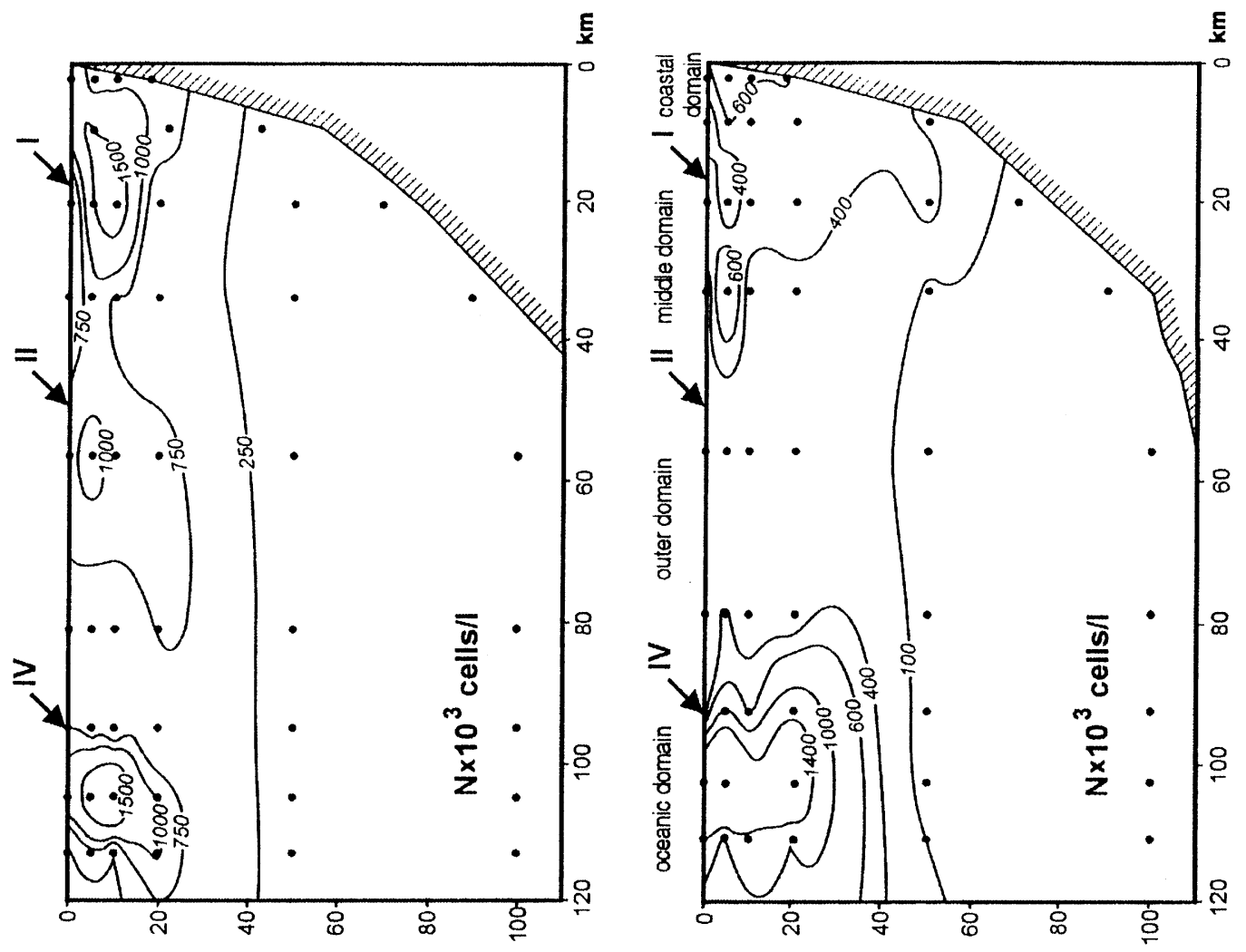

$\widehat{\oplus}$

$w$ ' 4 dəa

$\widehat{\vartheta}$

w 'ułdaO
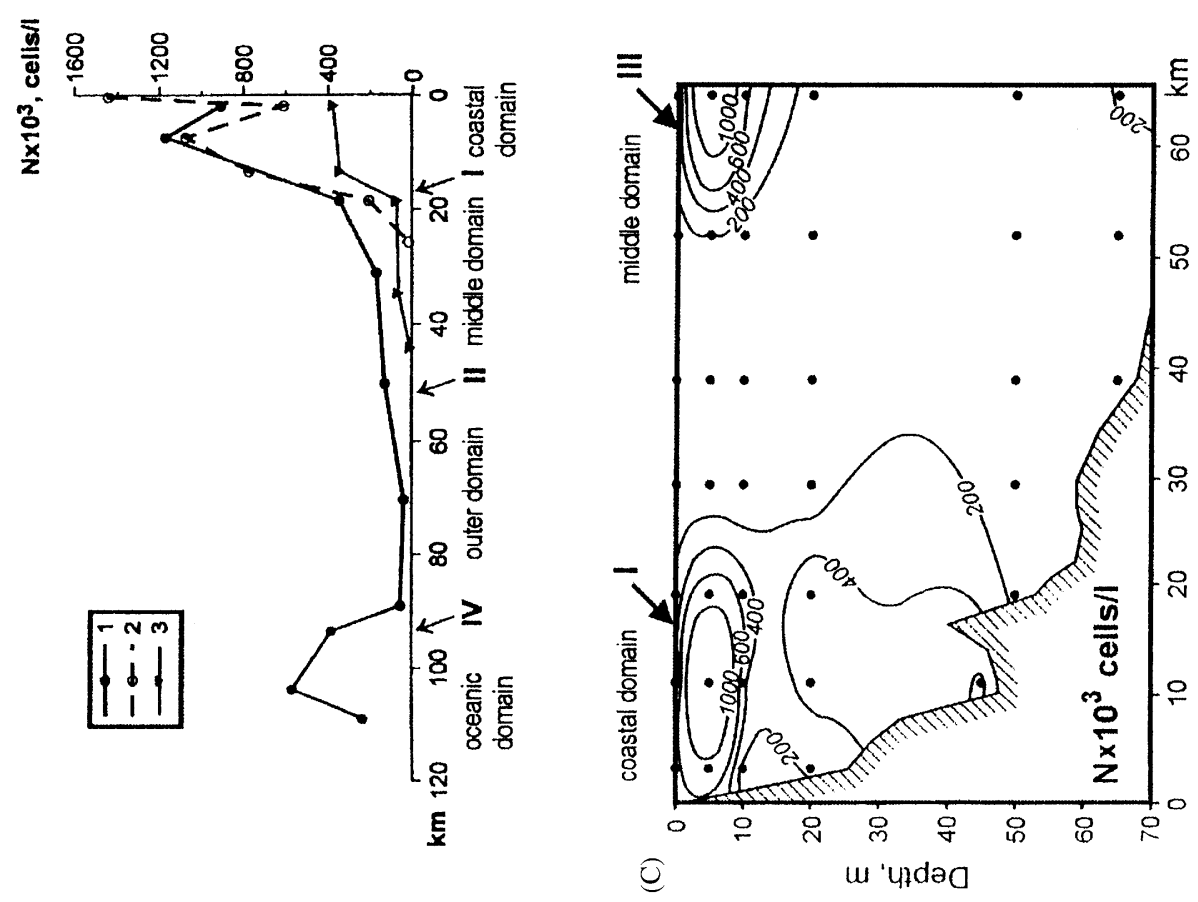

0
0
0
0
0

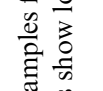

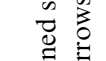
苛 芩

总

官 $\cong$

¿ ปे पू

$m$ 矛

空 तิ 导

=

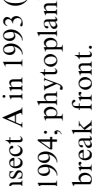

可产

을

ఏ를

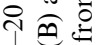

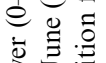

寻志

递艺

㐫矛

范

它

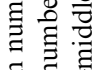

芯

흐를

흥 홍

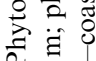


quantitative distribution of phytoplankton at the coastal front and in the coastal domain to the northeast of St. Paul Island had the same feature as that to the southwest of the island (Fig. 3C).

Surface primary production in the outer part of the coastal domain close to the coastal front near St. Paul Island in June and July 1994 were 123-175 and $114-288 \mathrm{mg} \mathrm{Cm}^{-3} \mathrm{~d}^{-1}$, respectively. The production rates at the front itself were lower: $78-115 \mathrm{mg} \mathrm{C} \mathrm{m}^{-3} \mathrm{~d}^{-1}$ in June and $38-53 \mathrm{mg}$ $\mathrm{C} \mathrm{m}^{-3} \mathrm{~d}^{-1}$ in July. In the adjacent areas of the middle domain phytoplankton production was at 21-94 and 30-41 $\mathrm{mg} \mathrm{C} \mathrm{m}^{-3} \mathrm{~d}^{-1}$, respectively.

In July 1993 and June 1994 higher concentrations of phytoplankton in the coastal domain and in the coastal front to the south of St. George Island were clearly visible in the biomass distributions (Figs. 4A and B). In June of 1994 phyto- plankton biomass at the coastal front and in the coastal domain near St. George Island reached very high values (respectively $5.7 \mathrm{~g}$ wet weight $\mathrm{m}^{-3}$ and $3.4 \mathrm{~g}$ wet weight $\mathrm{m}^{-3}$ in $0-20 \mathrm{~m}$ layer). In this year with a late cold spring the high phytoplankton concentrations were not due to growth of neritic species, but of large-size algae such as Rhizosolenia alata, $R$. hebetata $f$. semispina and Dactyliosolen fragilissimus. Phytoplankton production at the coastal front near St. George Island in June 1994 was $110 \mathrm{mg} \mathrm{C} \mathrm{m}^{-3} \mathrm{~d}^{-1}$ in the surface layer. In the coastal domain it reached $210 \mathrm{mg}$ $\mathrm{C} \mathrm{m}^{-3} \mathrm{~d}^{-1}$, while in the adjacent areas of the shelf it did not exceed $40-70 \mathrm{mg} \mathrm{C} \mathrm{m}^{-3} \mathrm{~d}^{-1}$.

The distribution pattern of heterotrophic nanoplankton in the early summer of 1994 showed no relationship to the coastal front. The mean concentrations of cells in the upper mixed
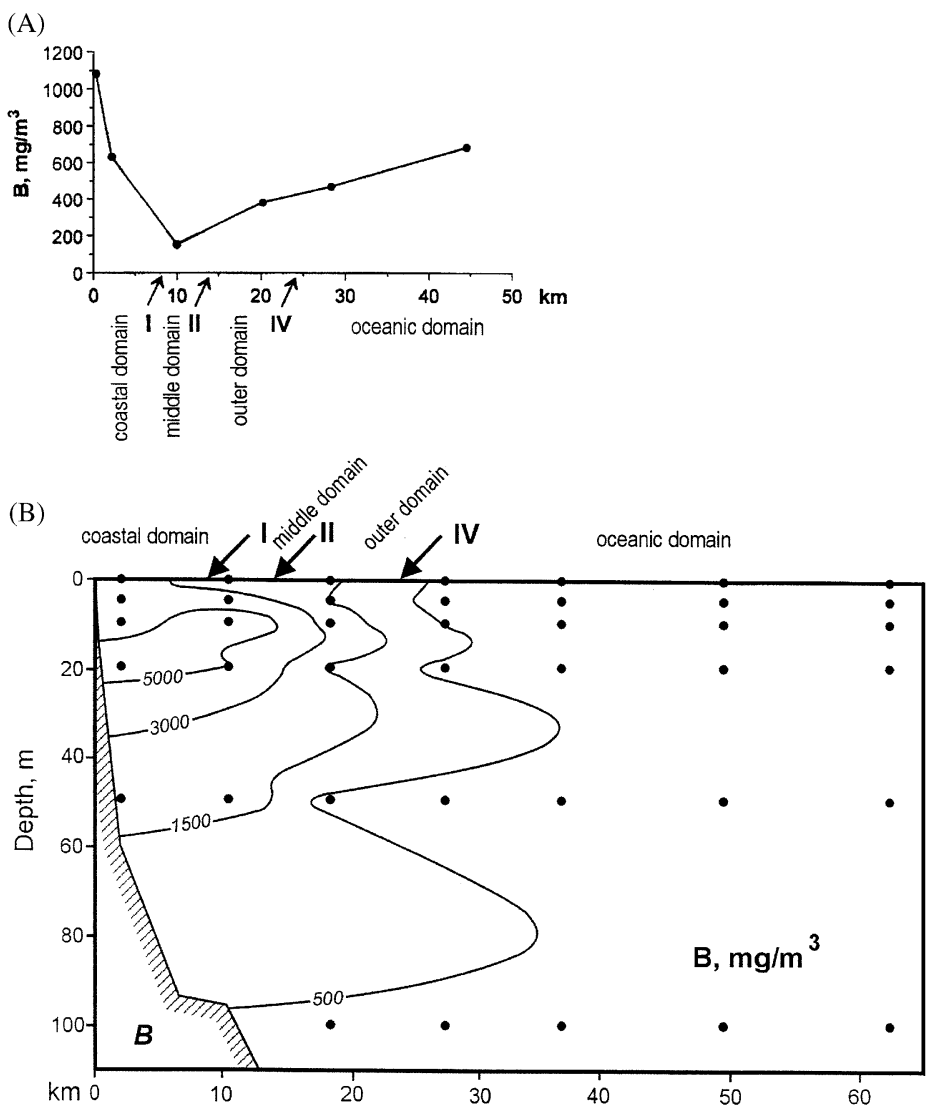

Fig. 4. (A) Phytoplankton mean wet biomass in upper mixed layer $(0-20 \mathrm{~m})$ along transect C in July 1993, based on combined samples from 0, 5, 10 and $20 \mathrm{~m}$; (B) phytoplankton wet biomass in transect C in June 1994. I-IV: the same as in Fig. 3. 
layer $(0-20 \mathrm{~m})$ in the coastal domain, coastal front and over the surrounding shelf generally varied over a range of $0.6-0.8 \times 10^{6}$ cells $1^{-1}$. At the end of July the numbers of nanoheterotrophs in the area to the southwest of St. Paul Island decreased but relatively high concentrations (up to $0.6 \times 10^{6}$ cells $1^{-1}$ ) persisted in the coastal domain (Fig. 5A). Elevated abundance of heterotrophic nanoplankton in the coastal front and coastal domain at that time also was clearly seen northeast of the island (Fig. 5B). Here the cell numbers reached 0.5$1.1 \times 10^{6}$ cells $^{-1}$, which was 5-10 times larger than in the middle domain. The quantitative distribution of heterotrophic nanoplankton in mid-summer was generally the same pattern as that of phytoplankton.

The coastal fronts near St. Paul and St. George Islands in summer did not affect mesozooplankton composition. The frontal areas and coastal domains of the islands were inhabited by the same zooplankton community as the surrounding middle shelf areas. Data from 1993 and 1994 showed that the coastal fronts seemed to have a different effect on the quantitative distribution of mesozooplankton to the southwest of St. Paul Island versus those to the northeast of St. Paul Island and to the south of St. George Island. In six transects out of seven, occupied in late May, June and July to the southwest of St. Paul Island, an increase in total biomass of mesozooplankton was observed at the coastal front or at the outer side of the front (Fig. 6A). In three transects to the northeast of St. Paul Island, also done in July 1993 and June, July 1994, the frontal area did not show higher total biomass of mesozooplankton (Fig. 6C). Similar patterns were also obtained in two transects to the south of St. George Island in July 1993 and in June 1994 (Fig. 6B).

Mesozooplankton wet biomass in the coastal frontal area over the $50-55 \mathrm{~m}$ isobath to the southwest of St. Paul Island reached a mean value of $440-656 \mathrm{mg}$ wet weight $\mathrm{m}^{-3}$ for the water column or $28.5-45.5 \mathrm{~g}$ wet weight $\mathrm{m}^{-2}$. The biomass at the coastal front was largely due to the concentration of the dominant species of shelf copepods, Calanus marshallae. Their maximum biomass reached $512-600 \mathrm{mg}$ wet weight $\mathrm{m}^{-3}$ in July 1994 (Fig. 7A). To the south of St. George
Island C. marshallae also showed increased biomass values in the coastal front area where it reached $240 \mathrm{mg}$ wet weight $\mathrm{m}^{-3}$ in contrast to $45 \mathrm{mg}$ wet weight $\mathrm{m}^{-3}$ in the coastal domain and $30 \mathrm{mg}$ wet weight $\mathrm{m}^{-3}$ in the adjacent middle shelf area (Fig. 7B). However, this well-pronounced aggregation of $C$. marshallae at the coastal front did not result in a relative increase of the total mesozooplankton biomass compared with the adjacent coastal and middle shelf domains. At the coastal front to the southwest of St. Paul Island high relative concentrations of other abundant forms of herbivorous and carnivorous zooplankton were observed, such as Euphausiacea and Parasagitta elegans (Fig. 7C). The distribution pattern of $P$. elegans, one of the major plankton predators over the shelf, often exhibited the highest biomass at the coastal front for the entire study area. High concentrations of $P$. elegans in the frontal zone or in its immediate vicinity in the coastal domain also were observed at the northeastern side of St. Paul Island.

The middle front (Fig. 1) was the only front in the Pribilof area that did not affect the distribution of plankton in the late spring and summer (Figs. 3, 5-7 and 9; Table 1). Neither to the southwest of St. Paul Island nor to the south of St. George Island was the front evident from increased numbers or biomass of any of the plankton components. The middle front also was not found to be a border for the distribution of particular phytoplankton or zooplankton species .

The newly defined shelf partition front (Fig. 1) produced a significant effect on quantitative distribution of phytoplankton and zooplankton. In early July 1993, phytoplankton mean numbers in the $0-20 \mathrm{~m}$ layer of the shelf partition front area was $0.6 \times 10^{6}$ cells $1^{-1}$ which significantly exceeded the values observed in the adjacent middle domain $\left(0.1-0.2 \times 10^{6}\right.$ cells $\left.^{-1}\right)$. This high value was largely formed by two species abundant over the shelf, Phaeocystis pouchetii and Rhizosolenia alata, which concentrated in the upper mixed $(0-20 \mathrm{~m})$ layer above the seasonal thermocline. In late July 1994 phytoplankton numbers at the front were an order of magnitude above those in the neighboring areas of the middle domain and reached $0.8 \times 10^{6}$ cells $1^{-1}$ (Fig. 3C). This value was comparable to 

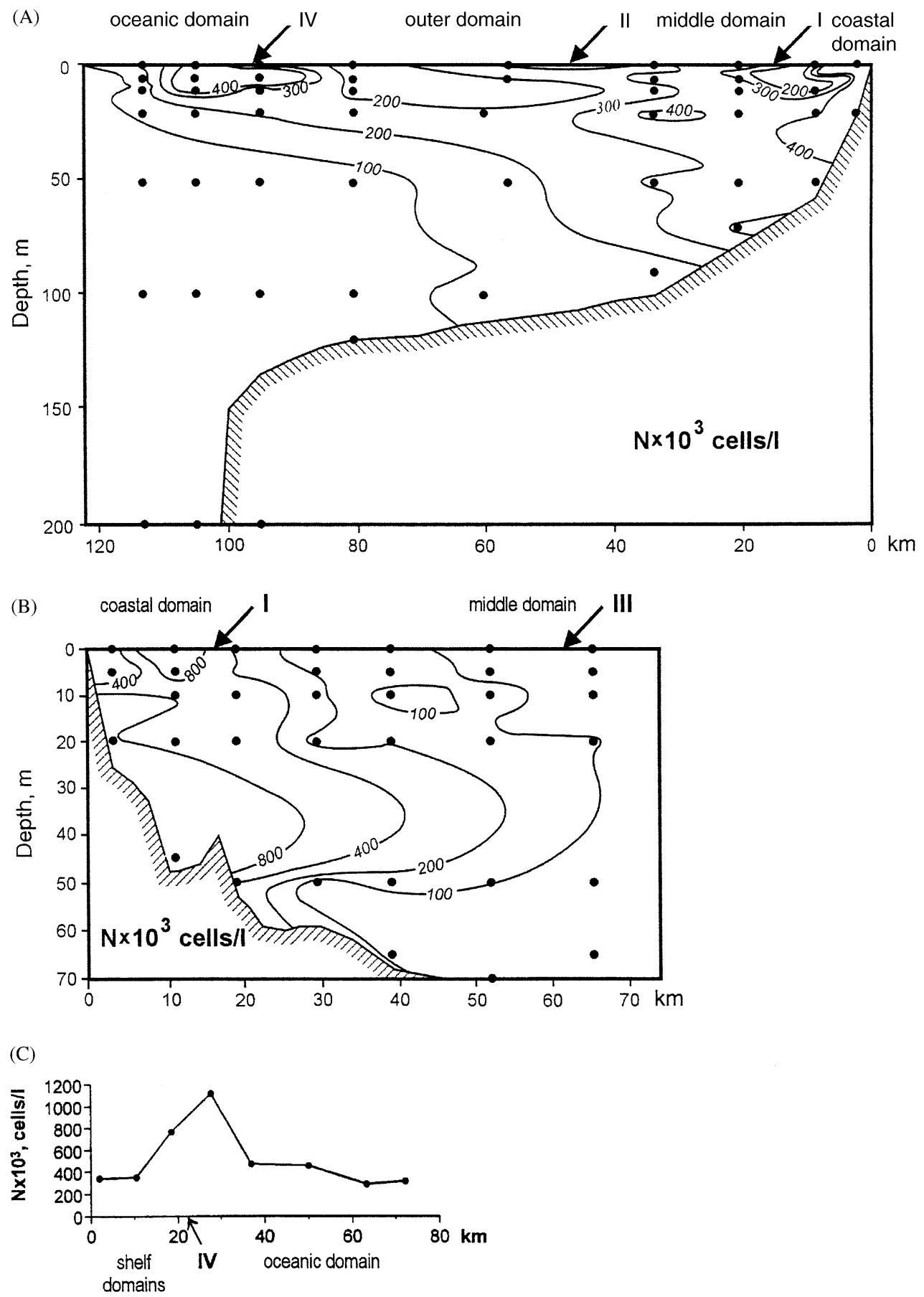

Fig. 5. Numbers of heterotrophic nanoplankton in July 1994 along transect A (A) and transect B (B); mean numbers of heterotrophic nanoplankton in upper mixed layer $(0-20 \mathrm{~m})$ along transect $\mathrm{C}$ in June 1993, based on combined samples from 0, 5, 10 and $20 \mathrm{~m}(\mathrm{C})$. I-IV: the same as in Fig. 3. 
(A)

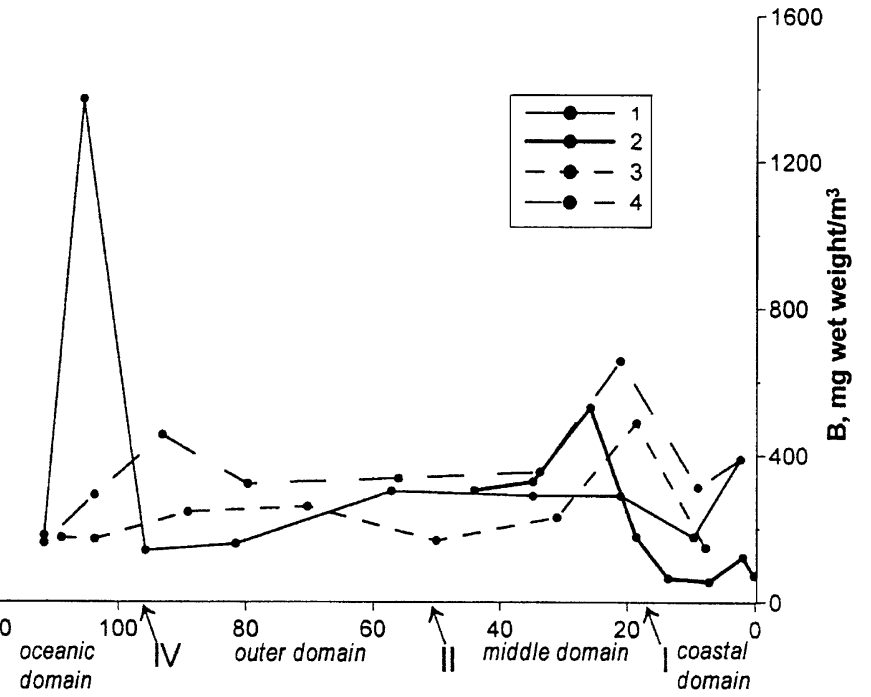

(B)

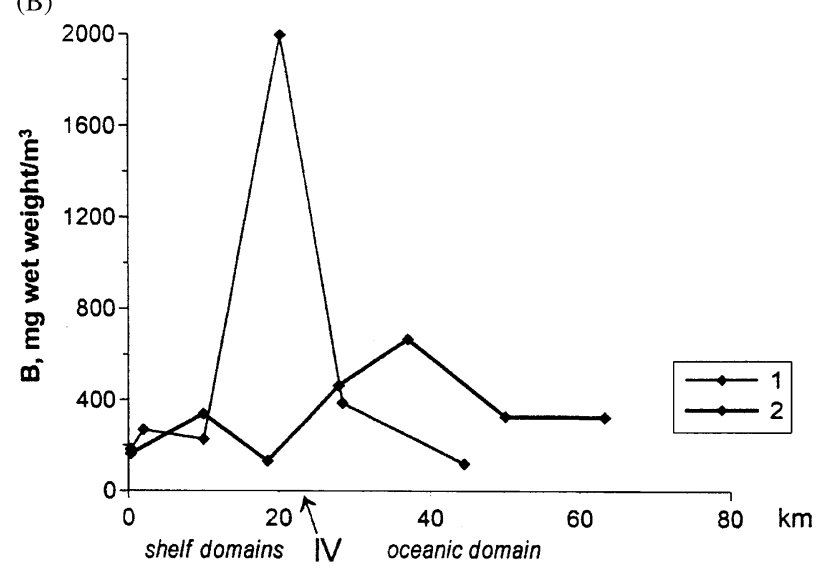

(C)

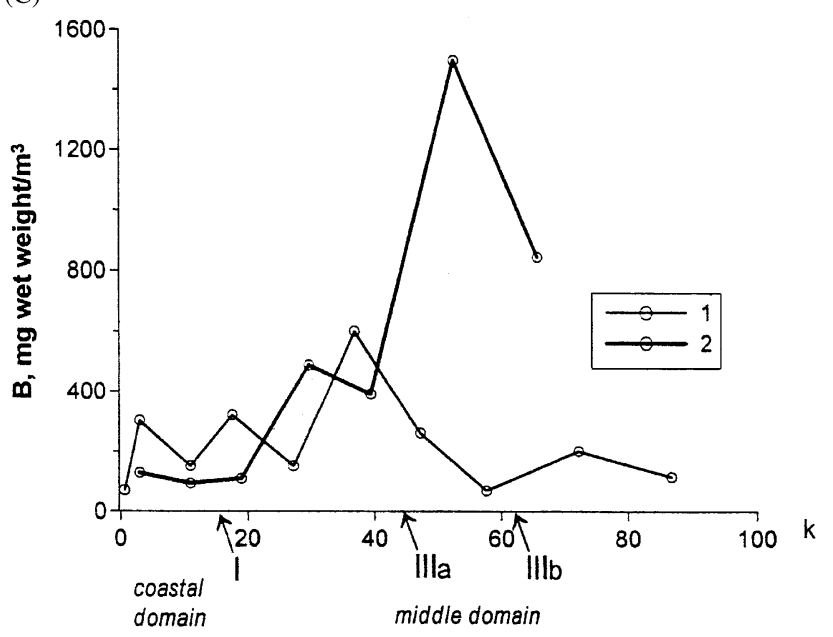


the number of cells in the coastal front and coastal domain. In contrast to the coastal front and coastal domain, the dominant phytoplankton at the shelf partition front were abundant small-sized species, Leptocylindrus minimus and Cylindrotheca closterium, which are typical for the summer community in the middle shelf domain. In July 1993 and 1994 most of the phytoplankton at the shelf partition front were concentrated in the upper mixed layer $(0-20 \mathrm{~m})$.

Surface primary production in July 1994 showed a low value at the shelf partition front, $29 \mathrm{mg}$ $\mathrm{C} \mathrm{m}^{-3} \mathrm{~d}^{-1}$, which did not differ from the values observed in the adjacent middle shelf areas, $31 \mathrm{mg}$ $\mathrm{Cm}^{-3} \mathrm{~d}^{-1}$. As soon as the surface layer at the frontal station had low phytoplankton numbers $\left(0.18 \times 10^{6}\right.$ cells $\left.1^{-1}\right)$, a ${ }^{14} \mathrm{C}$ primary production experiment was initiated with a sample taken from 5-m, where phytoplankton numbers reached their maximum concentration of $2.0 \times 10^{6}{\text { cells } 1^{-1}}^{-1}$ (Fig. 3C). Primary production in the layer of maximum phytoplankton concentration reached $207 \mathrm{mg} \mathrm{C} \mathrm{m}^{-3} \mathrm{~d}^{-1}$, which was close to the highest values observed in the productive coastal domain and shelf break areas in June.

Quantitative estimates of heterotrophic nanoplankton in the shelf partition front area, made in July 1994, gave nearly the same low values as those observed in adjacent areas of the middle shelf, $0.09-0.11 \times 10^{6}$ cells $1^{-1}$. The values were an order of magnitude below those found in the same period of time at the coastal front and in the coastal domain of St. Paul Island (Fig. 5B).

The data obtained in July 1993 and 1994 revealed a significant effect of the shelf partition front on the quantitative distribution of mesozooplankton. In 1993 in the southwestern periphery of the front an increase in the total biomass of zooplankton was evident with a mean value of $600 \mathrm{mg}$ wet weight $\mathrm{m}^{-3}$ (42 $\mathrm{g}$ wet weight $\mathrm{m}^{-2}$ ) for the 69-m water column (Fig. 6C-1). In the middle shelf area to the northeast of the St. Paul Island the mean mesozooplankton biomass during that period varied from 70 to $320 \mathrm{mg}$ wet weight $\mathrm{m}^{-3}$. Even higher concentrations of mesozooplankton near the southwestern margin of the shelf partition front were observed in late July 1994 (Fig. 6C-2). Here the mean biomass for the water column reached $1500 \mathrm{mg}$ wet weight $\mathrm{m}^{-3}$, while the integrated value was $105 \mathrm{~g}$ wet weight $\mathrm{m}^{-2}$. In the frontal zone, the respective values were $850 \mathrm{mg}$ wet weight $\mathrm{m}^{-3}$ and $58 \mathrm{~g}$ wet weight $\mathrm{m}^{-2}$. In the neighboring middle shelf areas, the biomass of zooplankton at that time did not exceed 400 $450 \mathrm{mg}$ wet weight $\mathrm{m}^{-3}$. In both years the major fraction of zooplankton biomass $(>97 \%)$ in the shelf partition front area was contributed by the herbivorous copepod Calanus marshallae, while the total share of other species and groups of zooplankton was below 5-40 $\mathrm{mg}$ wet weight $\mathrm{m}^{-3}$. Distributions of $C$. marshallae along transects to the northeast of St. Paul Island in July 1993 and 1994 are shown in Fig. 8A. In the frontal area and at its southwest periphery, this species was concentrated in the layer below the thermocline, where the mean biomass (20-69 m layer) reached $780 \mathrm{mg}$ wet weight $\mathrm{m}^{-3}$ in 1993 , while in 1994 it was $2100 \mathrm{mg}$ wet weight $\mathrm{m}^{-3}$. The respective values for surface $0-20 \mathrm{~m}$ layer were as small as 3-5 mg wet weight $\mathrm{m}^{-3}$. In addition to $C$. marshallae, the oceanic copepod Neocalanus cristatis, an alien to the middle shelf community of this area, was found to concentrate in the shelf partition front zone (Fig. 8B). Aggregations of $N$. cristatis at the southwestern periphery of the shelf partition front were not high with a biomass level of just $7-10 \mathrm{mg}$ wet weight $\mathrm{m}^{-3}$, but they were apparent compared to the complete absence of the species in the middle shelf area to the northeast of St. Paul Island.

The shelf break front (Fig. 1) in late spring and summer was not a strict border in the distribution of phytoplankton species. Nevertheless, the front exhibited a sharp decline in the abundance of some species dominating oceanic community, Pseudonitzschia subcurvata, $P$. delicatissima, in

Fig. 6. Total zooplankton wet biomass: (A) along transect A in May (2), June (3) 1993 and June (1), July (4) 1994; (B) along transect C in July 1993 (1) and June 1994 (2); (C) along transect B in July 1993 (1) and July 1994 (2). Biomass average for 0-100 m or 0 m-bottom is shallower. I-IV: the same as in Fig. 3; IIIa and IIIb location of shelf partition front in July 1993 and July 1994, respectively. 
(A)

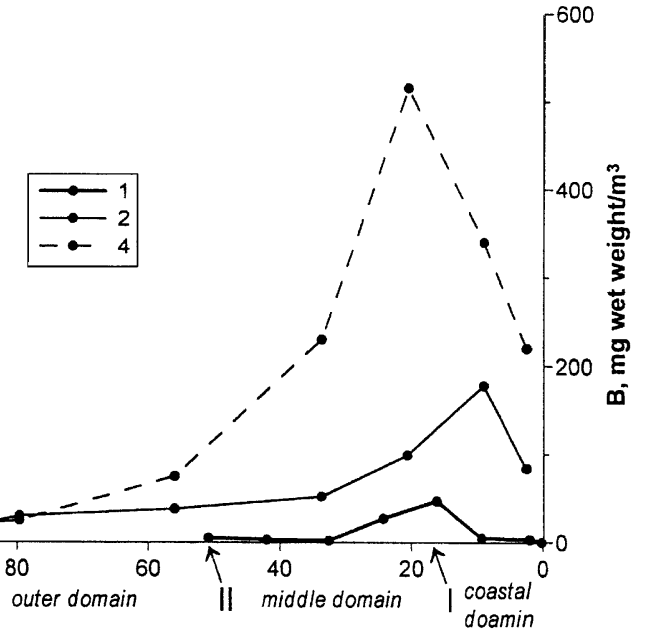

(B)

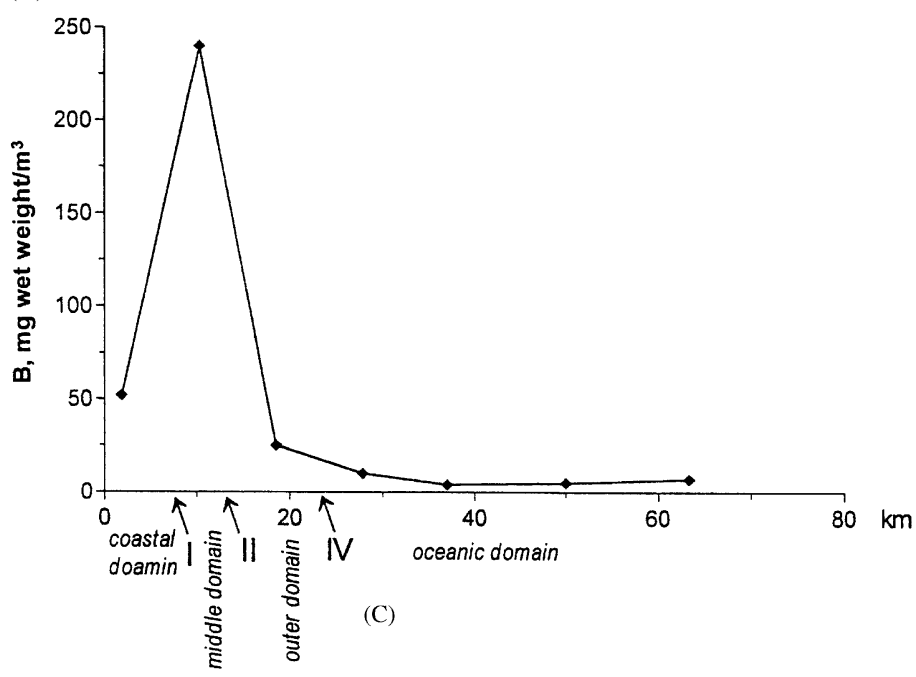

(C)

B, \%

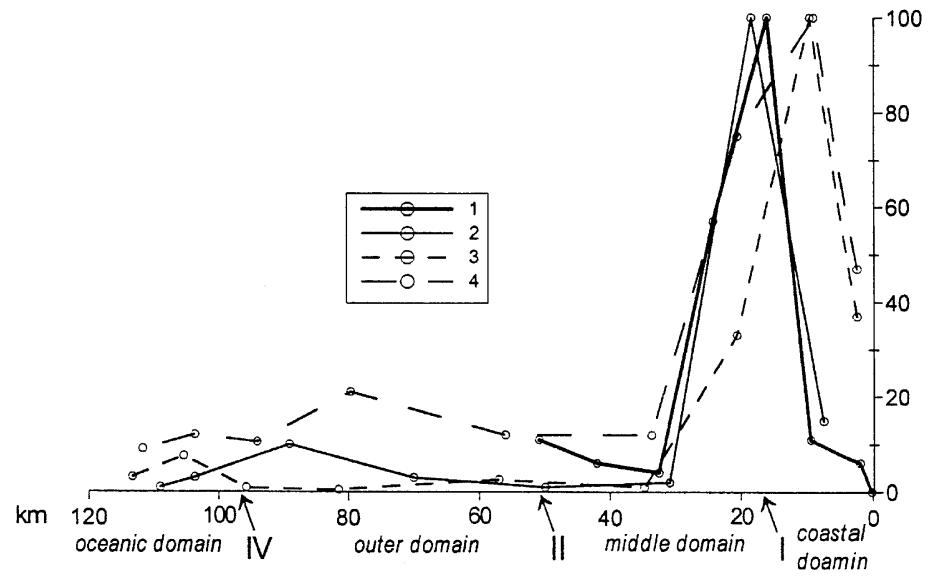




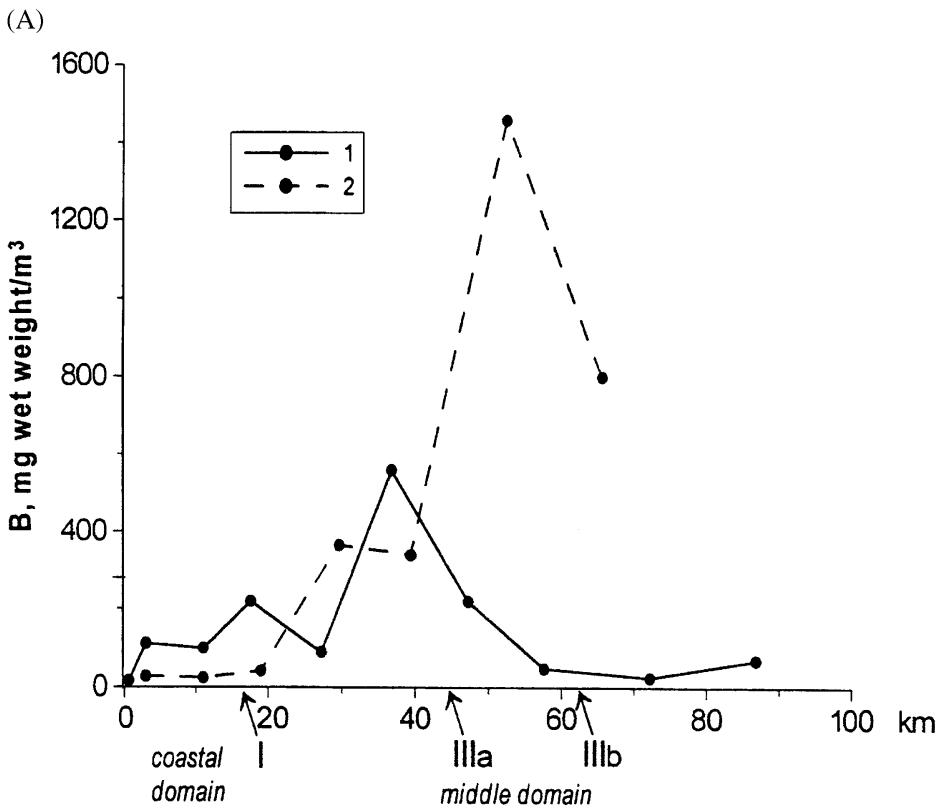

(B)

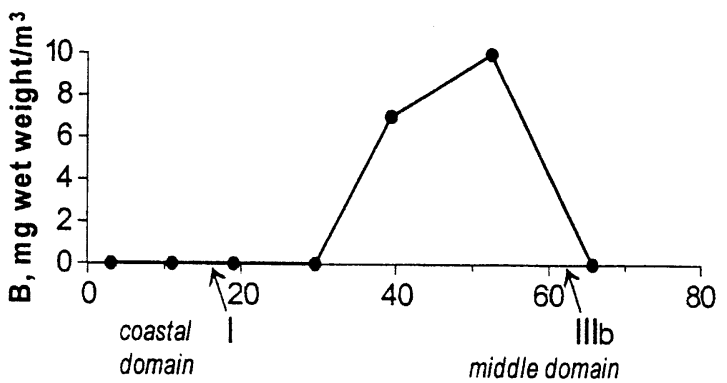

Fig. 8. Distribution of abundant zooplankton species. (A) Calanus marshallae wet biomass along transect B in July 1993 (1) and July 1994 (2); (B) Neocalanus cristatus wet biomass along transect B in July 1994. Biomass average for $0 \mathrm{~m}$ - bottom. I-IV: the same as in Fig. 3; IIIa and IIIb location of shelf partition front in July 1993 and July 1994, respectively.

transition from the oceanic domain to outer shelf (Table 1).

In June 1993 a five-fold increase of phytoplankton numbers in comparison with outer domain was attributed to the shelf break front area to the southwest of St. Paul Island (Fig. 3A). The highest numbers, up to $0.6 \times 10^{6}$ cells $1^{-1}$ in the upper mixed layer $(0-20 \mathrm{~m})$, were observed not in the frontal zone itself, but at its oceanic side. In the frontal zone the numbers of phytoplankton cells were $0.4 \times 10^{6}$ cells $1^{-1}$, while in the outer domain they were an order of magnitude lower. High numbers of phytoplankton in the shelf break front, and in the oceanic domain area adjacent to it, were 
due to Phaeocystis pouchetii. This species was responsible for $88-94 \%$ of the total cell numbers. In June 1994 the pattern of quantitative distribution of phytoplankton in the shelf break front area was similar to 1993 (Fig. 3B). The highest cell numbers $\left(1.9 \times 10^{6}\right.$ cells $\left.1^{-1}\right)$ in the $0-20 \mathrm{~m}$ mixed layer above the thermocline were observed in the close proximity to the front at its oceanic side, as it was in 1993. Phytoplankton numbers in the neighboring areas of the outer shelf and oceanic domains at that time were $0.4 \times 10^{6}$ and $0.5 \times 10^{6}$ cells $1^{-1}$, respectively. Unlike the situation in June 1993, the dominant group of algae in the shelf break area and the adjacent part of oceanic domain included, in addition to Phaeocystis pouchetii, a small-sized Thalassiosira spp., Cylindrotheca closterium, and Eutreptia lanowii. This group of species was responsible for over $50 \%$ of the total cell numbers. A similar trend in the quantitative distribution of phytoplankton at the outer shelf border to the southwest of St. Paul Island persisted in July 1994 (Fig. 3D). The highest numbers of cells in the upper mixed layer $(0-20 \mathrm{~m})$ at the outer oceanic periphery of the shelf break front were $2.3 \times 10^{6}$ cells $1^{-1}$ and in the frontal zone itself the concentration was $0.8 \times 10^{6}$ cells $1^{-1}$. Phytoplankton abundance in the oceanic domain at that time was $1.1 \times 10^{6}$ cells $1^{-1}$, and in the outer domain the value was much lower at $0.1-0.3 \times 10^{6}$ cells $1^{-1}$. The group of species dominating by number of cells in the frontal zone and in the adjacent areas included the small-sized diatoms Pseudonitzschia subcurvata and $P$. delicatissima, which contributed over $50 \%$ of total numbers of phytoplankton. The largest contribution to phytoplankton biomass at the outer shelf border was that of the large-sized Corethron criofilum. In the area of the phytoplankton maximum at the oceanic side of the shelf break front, this species was responsible for $75 \%$ of the total biomass (330 mg wet weight $\mathrm{m}^{-3}$ ). In June and July 1994 significant increases in abundance of the neritic diatom species, Chaetoceros socialis, C. diadema, C. debilis, C. concavicornis, Thalassiosira nordenskioeldii, were observed in the area of the peak phytoplankton biomass (Table 1). For instance, in June 1994 C. socialis, which was absent over the outer shelf, reached numbers of $1.8 \times 10^{4}$ cells $1^{-1}$ at the oceanic side of the shelf break front. The numbers of $C$. debilis in the outer domain were below 200 cells $1^{-1}$, while in the phytoplankton peak abundance area at the outer side of the front they increased up to $4.5 \times 10^{4}$ cells $1^{-1}$. Below we show that the same phenomenon was observed at the shelf break front to the south of St. George Island.

In 1994 the area of high abundance of phytoplankton at the oceanic side of the shelf break front to the southwest of St. Paul Island also featured a relatively high level of primary production. Phytoplankton production in the surface layer at the oceanic side of the front in June was

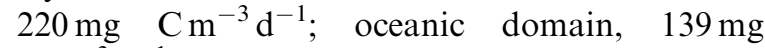
$\mathrm{C} \mathrm{m}^{-3} \mathrm{~d}^{-1}$; shelf break frontal zone and outer domain, 96 and $127 \mathrm{mg} \mathrm{C} \mathrm{m}^{-3} \mathrm{~d}^{-1}$, respectively. In July primary production at the outer side of the front was $48 \mathrm{mg} \mathrm{Cm} \mathrm{Cm}^{-3} \mathrm{~d}^{-1}$; oceanic domain,

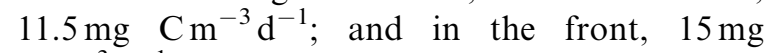
$\mathrm{C} \mathrm{m}^{-3} \mathrm{~d}^{-1}$.

The distribution of heterotrophic nanoplankton in the areas adjacent to the shelf break southwest of St. Paul Island in July 1994 showed the same pattern as the phytoplankton (Fig. 5A). The highest numbers of nanoheterotrophs, located in the oceanic domain area adjacent to the shelf break front were $0.46 \times 10^{6}$ cells $1^{-1}$ and in the frontal zone were $0.35 \times 10^{6}$ cells $1^{-1}$. The neighboring areas in the oceanic domain and the outer shelf featured 2-3-fold lower values, $0.15 \times 10^{6}$ and $0.19 \times 10^{6}$ cells $^{-1}$, respectively. A month earlier, in June, the effect of shelf break front on distribution of heterotrophic nanoplankton was not pronounced. The distribution of this component of plankton in the outer shelf area and the adjacent deep-water areas was relatively invariant, with a range of $0.65 \times 10^{6}$ to $0.83 \times 10^{6}$ cells $^{-1}$.

In three transects occupied in June 1993, June and July 1994 to the southwest of St. Paul Island, the offshore side of the shelf break front was a pronounced boundary in the distribution of the dominant species of shelf copepod, Calanus marshallae (Fig. 7A). Abundant copepod species from the oceanic community penetrated through the front into the outer shelf area in large numbers (Fig. 9). The penetration was also equally true for the shelf break front to the south of St. George 
(A)

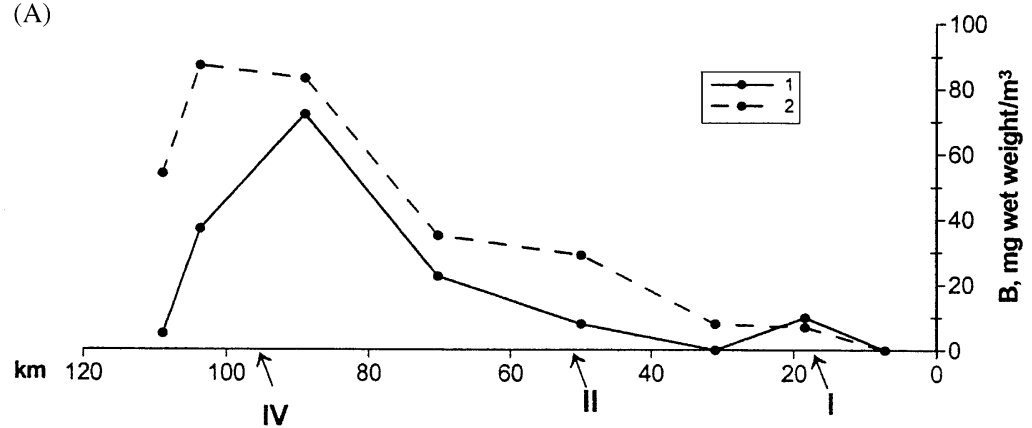

(B)
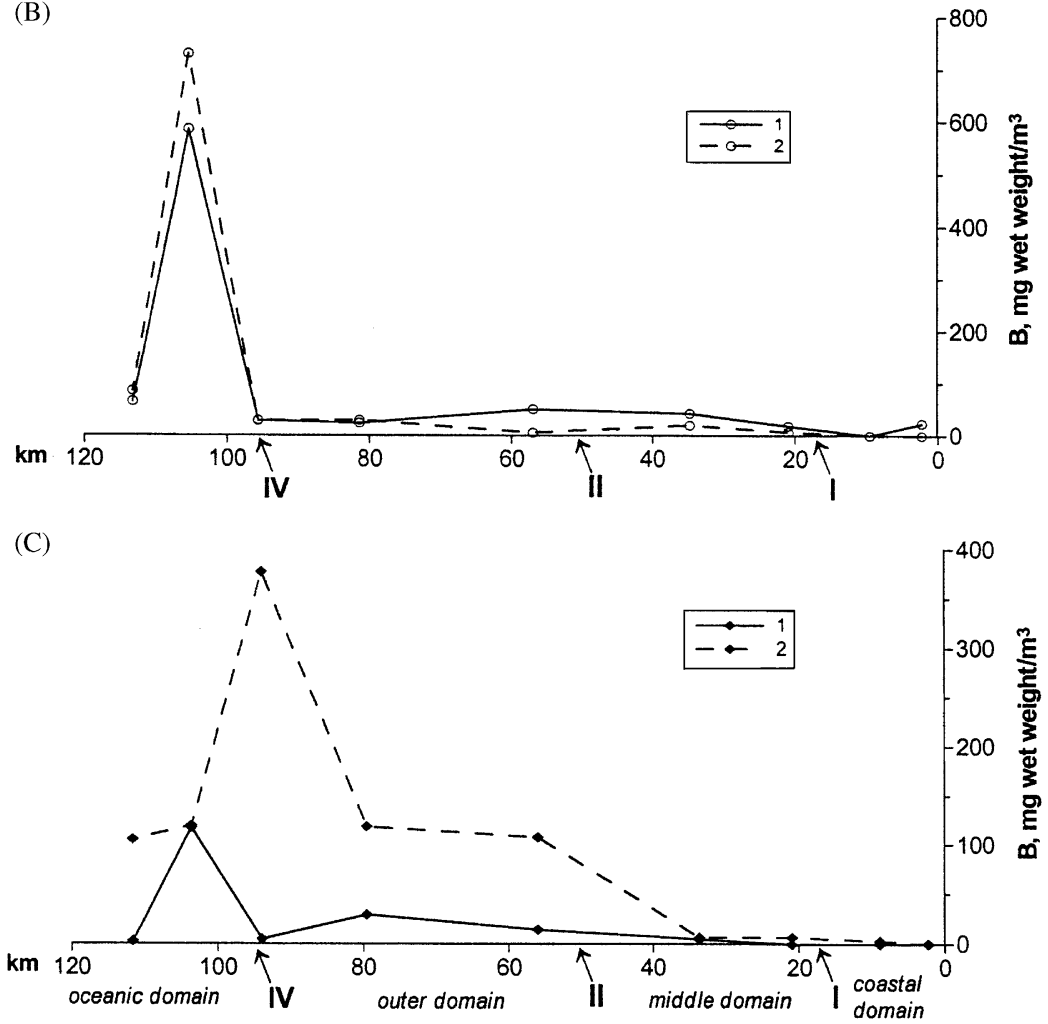

Fig. 9. Distribution of abundant zooplankton species. Neocalanus cristatus (1) and Eucalanus bungii (2) wet biomass along transect A in June 1993 (A), June 1994 (B) and July 1994 (C). Biomass in 0-100 m or 0 m-bottom if shallower. I-IV: the same as in Fig. 3.

Island and significantly affected the composition of zooplankton in aggregations attributed to the shelf break front (Figs. 10A and B).

The shelf break front in the June 1993 transect to the southwest of the St. Paul Island was not apparent in the distribution of the total mesozooplankton biomass, while it was clearly visible in the distribution of abundant species of copepods
(Figs. 6A and 9A). Aggregations at the front were formed by the oceanic species, Neocalanus cristatus and Eucalanus bungii. The mean mesozooplankton biomass at the front within the $0-100 \mathrm{~m}$ layer was $250 \mathrm{mg}$ wet weight $\mathrm{m}^{-3}$, while the contributions of the above species were 80 and $90 \mathrm{mg}$ wet weight $\mathrm{m}^{-3}$, respectively. In June and July 1994, the high concentrations of zooplankton were associated 

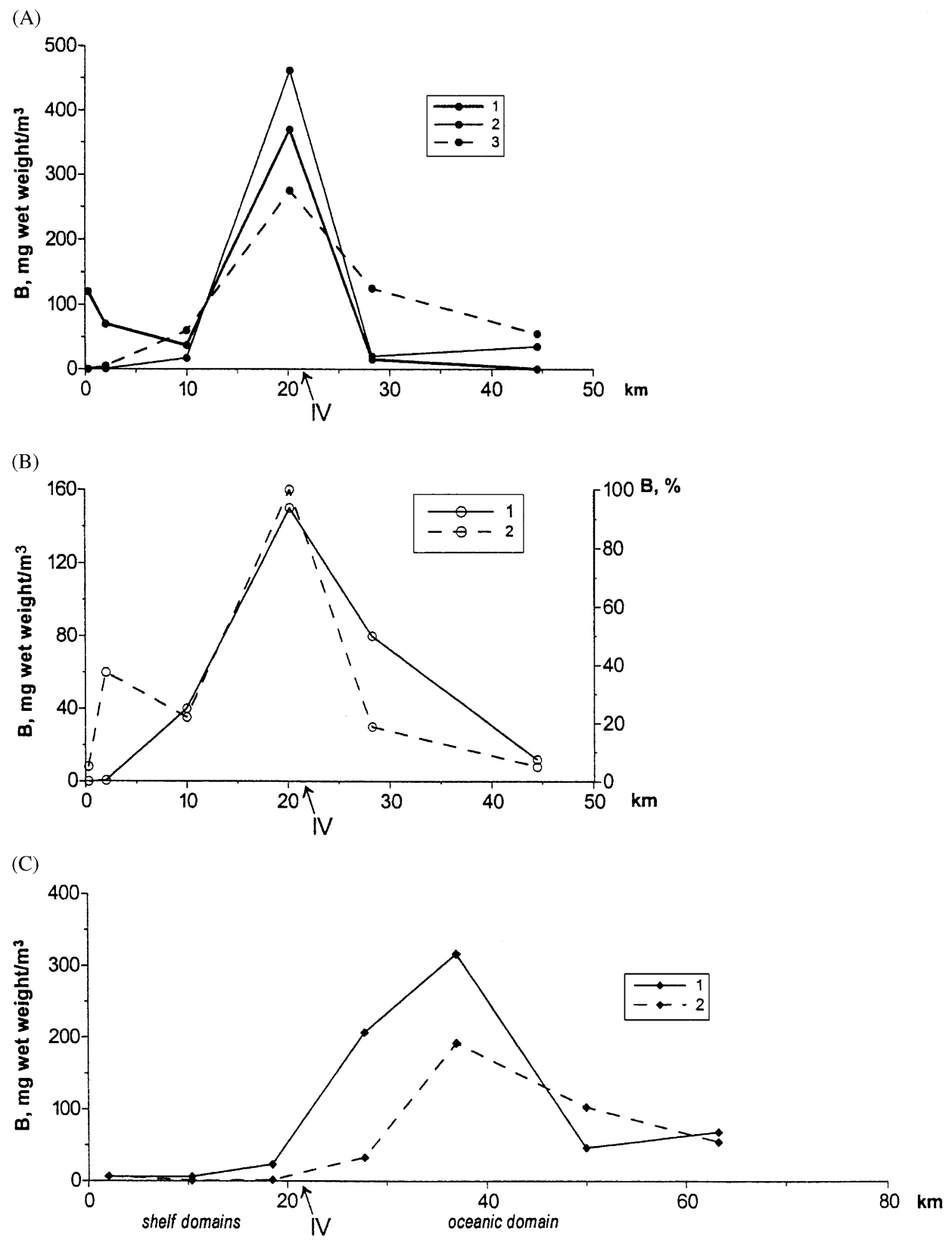

Fig. 10. Distribution of abundant zooplankton species. (A) Calanus marshallae (1), Neocalanus cristatus (2), and Eucalanus bungii (3) wet biomass along transect C in July 1993; (B) Neocalanus plumchrus (+N.flemingeri) wet biomass (1) and Euphausicea relative abundance (\%, wet biomass) (2) along transect C in July 1993; (C) N. cristatus (1) and E. bungii (2) wet biomass along transect C in June 1994. Biomass average for 0-200 m or $0 \mathrm{~m}$-bottom if shallower. I-IV: the same as in Fig. 3.

with the shelf break frontal area (Fig. 6A). The zooplankton biomass in the area adjacent to the front on the oceanic side in June reached a mean of
$1370 \mathrm{mg}$ wet weight $\mathrm{m}^{-3}$ for the $0-100 \mathrm{~m}$ layer. In the oceanic domain at that time the mean biomass was $180 \mathrm{mg}$ wet weight $\mathrm{m}^{-3}$, while over the outer 
shelf it was at $120-300 \mathrm{mg}$ wet weight $\mathrm{m}^{-3}$. The oceanic species $N$. cristatus and $E$. bungii aggregated in the frontal area with maximum biomasses of 686 and $730 \mathrm{mg}$ wet weight $\mathrm{m}^{-3}$, respectively (Fig. 9B). In July 1994 the largest mean zooplankton biomass, $430 \mathrm{mg}$ wet weight $\mathrm{m}^{-3}$ within the 0 $100 \mathrm{~m}$ layer, was located in the shelf break front zone (Fig. 6A). At that time the main contributors to the biomass were the same oceanic copepods, $N$. cristatus $\left(105 \mathrm{mg}\right.$ wet weight $\left.\mathrm{m}^{-3}\right)$ and E. bungii (380 $\mathrm{mg}$ wet weight $\mathrm{m}^{-3}$ ) (Fig. 9C).

Total phytoplankton biomass in July 1993 to the south of St. George Island increased up to $685 \mathrm{mg}$ wet weight $\mathrm{m}^{-3}$ (mean for $0-20 \mathrm{~m}$ ) at $15 \mathrm{~km}$ to the oceanic side of the shelf break front (Fig. 4A). In the front and adjacent shelf areas, it was $380-470 \mathrm{mg}$ wet weight $\mathrm{m}^{-3}$. In June 1994 no pronounced changes in the quantitative distribution of phytoplankton related to the shelf break front were observed (Fig. 4B). The mean biomass in the upper mixed layer $(0-20 \mathrm{~m})$ in the shelf break front, as well as in adjacent areas, was low and varied within a narrow range from 250 to $350 \mathrm{mg}$ wet weight $\mathrm{m}^{-3}$. In July 1993 the phytoplankton in the high biomass area at the oceanic side of the front was dominated by the diatoms Neodenticula seminae, Thalassiosira sp., Chaetoceros diadema, $C$. concavicornis. The latter two species are neritic and in the summertime were the major contributors to phytoplankton abundance and biomass in the coastal fronts and coastal domains of St. Paul and St. George Islands. The phytoplankton maximum located at the oceanic side of the shelf break front exhibited increased numbers of some other species normally abundant in the coastal zones of the islands, in particular $C$. debilis and $T$. nordenschioeldii. Increased numbers of neritic diatom species in the area also were observed in June 1994 when the phytoplankton peak in the shelf break front was not pronounced and Phaeocystis pouchetii dominated the phytoplankton abundance.

In June 1994, in spite of the absence of a pronounced phytoplankton peak at the oceanic side of the shelf break front to the south of St. George Island, surface primary production in this area was relatively high and comparable to that in the coastal front and the coastal domain areas, reaching $145 \mathrm{mg} \mathrm{C} \mathrm{m}^{-3} \mathrm{~d}^{-1}$. In the outer shelf area at that time, the production was $40-70 \mathrm{mg}$ $\mathrm{C} \mathrm{m}^{-3} \mathrm{~d}^{-1}$.

The transect occupied in June 1994 to the south of St. George Island was the only instance in this study where a trend related to a front could be found in the bacterioplankton distribution. The highest numbers of pelagic bacteria $\left(1.4 \times 10^{6}\right.$ cells $\left.\mathrm{ml}^{-1}\right)$ in the upper mixed layer $(0-20 \mathrm{~m})$ were observed at the oceanic side of the shelf break front. In the front their concentration was $0.85 \times 10^{6}$ cells ml $^{-1}$, while in adjacent shelf areas it did not exceed $0.7 \times 10^{6}$ cells $\mathrm{ml}^{-1}$.

In June 1994 a high abundance of heterotrophic nanoplankton was observed at the shelf break front to the south of St. George Island (Fig. 5C). The mean cell numbers in the $0-20 \mathrm{~m}$ layer above the thermocline at the front reached $0.75-1.1 \times 10^{6}$ cells $1^{-1}$, which exceeded the maximum concentrations observed in the coastal domains of the islands. The background values of the numbers of planktonic nanoheterotrophs for the shelf area at that time were $0.35-0.38 \times 10^{6}$ cells $1^{-1}$, while in the oceanic domain they were $0.30-0.47 \times 10^{6}$ cells $1^{-1}$.

The distribution of mesozooplankton south of St. George Island in July 1993 showed an example of the biomass peak related to the inner shelf side of the shelf break front (Fig. 6B). There, at the $135 \mathrm{~m}$ isobath and $20 \mathrm{~km}$ away from the island, the highest biomass values for the Pribilof area were observed: $1700 \mathrm{mg}$ wet weight $\mathrm{m}^{-3}$ on average for the water column and $2000 \mathrm{mg}$ wet weight $\mathrm{m}^{-3}$ for $0-100 \mathrm{~m}$ layer. The values were an order of magnitude larger than those observed in the adjacent areas over the shelf and in the oceanic domain. In the layers below the seasonal thermocline $(20-100 \mathrm{~m})$, the mesozooplankton mean biomass reached $2500 \mathrm{mg}$ wet weight $\mathrm{m}^{-3}$, while its total value within the water column was $230 \mathrm{~g}$ wet weight $\mathrm{m}^{-2}$. The peak of the zooplankton biomass at the inner side of the shelf break front was comprised of a "mixed" zooplankton community, which included the dominant shelf copepod, Calanus marshallae, as well as abundant oceanic species, Neocalanus cristatus, N. plumchrus $(+N$. flemingeri) and Eucalanus bungii (Figs. 10A and $\mathrm{B})$. The share of shelf community species $C$. 
marshallae in the maximum zooplankton biomass associated with the front was $20 \%$ while the total share of oceanic copepods was $45 \%$. A pronounced aggregation at inner side of the shelf break front south of St. George Island also was formed by the euphausiid, Thysanoessa inermis (Fig. 10B). The plankton nets used for sampling do not allow an adequate estimation of the euphausiid biomass, so one can only state that at the front it was 2.5-5 times higher than in the adjacent shelf and oceanic domain areas.

In June 1994, within a background of a relatively weak shelf break front to the south of St. George Island, the distribution of zooplankton over the outer border of the shelf was similar to that observed to the southwest of St. Paul Island. The biomass peak (mean of $710 \mathrm{mg}$ wet weight $\mathrm{m}^{-3}$ for the $0-100 \mathrm{~m}$ layer) was attributed to the oceanic domain area immediately adjacent to the shelf break front and was largely formed by oceanic community copepods, Neocalanus cristatus $\left(330 \mathrm{mg}\right.$ wet weight $\mathrm{m}^{-3}$ ) and Eucalanus bungii (200 $\mathrm{mg}$ wet weight $\mathrm{m}^{-3}$ ) (Fig. 10C).

\section{Discussion}

Three out of the four types of oceanographic fronts found within the $100 \mathrm{~km}$ zone around the Pribilof Islands, the coastal front, shelf partition front and shelf break front, have significant effects on the distribution of plankton.

The coastal front and the coastal domain adjacent to St. Paul and St. George Islands (Fig. 1) in the late spring and summer exhibit relatively high concentrations of phytoplankton compared with the surrounding middle domain. This also was found in previous observations of chlorophyll distributions (Schneider et al., 1990; Coyle and Cooney, 1993; Flint et al., 1994, 1996; Decker and Hunt, 1996; Hunt et al., 1996; Brodeur et al., 1997). This research showed that phytoplankton numbers and biomass in the coastal front and coastal domain in summer time reached values which were reported as a maximum for the spring bloom period over the shelf (Goering, and Iverson, 1981; Sukhanova et al., 1999). Generally, the phytoplankton abundance in the coastal front and in the coastal domain were similar (Figs. 3C and $4 \mathrm{~B}$ ) or the highest concentrations of phytoplankton were associated with the coastal domain (e.g. Figs. 3A and D and Fig. 4A). According to previous observations of chlorophyll distributions, the phytoplankton maximum was occasionally found in the coastal front only (Schneider et al., 1990; Coyle and Cooney, 1993; Hunt et al., 1996; Brodeur et al., 1997).

The coastal domains in the Pribilof archipelago have the same or similar width as the coastal fronts (Flint et al., 1994, 1996; Stabeno et al., 1999; Poyarkov, 2000), and the processes associated with the fronts affect plankton communities both in the frontal zones and coastal domains. We hypothesize that the following physical processes are crucial for formation and maintenance of the high phytoplankton production and concentration in these areas. First, a relatively weak thermocline in the inner part of the coastal front may be easily eroded by wind mixing. Combined with intensive vertical mixing of the whole water column and topographically enhanced currents over the shallow areas near the islands (Kowalik, 1999; Stabeno et al., 1999), this enables an influx of subthermocline waters, rich in nutrients, into the euphotic zone and their rapid spread across the coastal zones of the islands. The second mechanism promoting nutrient regime favorable for intensive phytoplankton development within the coastal domain is linked to the cross-frontal exchange in the coastal front. Nutrient-rich waters below the thermocline from the surrounding middle domain occasionally penetrate into the coastal domain, which was reflected in weakening of temperature and nutrient horizontal gradients in the nearbottom part of the front (Flint et al., 1996; Poyarkov and Emelianov, 2000; Poyarkov, 2001). Elevated nutrient concentrations in the coastal zones of St. Paul and St George Islands were observed in late spring, summer (Flint et al., 1994, 1996) and early fall (Brodeur et al., 1997). A transect occupied to the northeast from St. Paul Island in July 1994 gives an example of such an enrichment (Fig. 2C and D).

Periodic enrichment of the nutrients in coastal fronts and coastal domains of the Pribilof Islands maintain the summer phytoplankton blooms that 
are typical for these areas (Flint et al., 1996; Sukhanova et al., 1999). Favorable conditions for the development of phytoplankton in these areas result in high values of primary production in summer. The highest integrated values measured in the coastal fronts and coastal domains in JuneAugust of 1992-1994 were from 2.7 to $4.9 \mathrm{mg}$ $\mathrm{C} \mathrm{m}^{-2} \mathrm{~d}^{-1}$ (Kopylov et al., 2002), which are similar to phytoplankton production reported for the spring bloom period over the eastern shelf (Starodubtsev, 1970; Goering and Iverson, 1978; Whitledge et al., 1986). The inner part of the coastal front presents the most favorable conditions for phytoplankton development because of coexistence of vertical stratification and elevated nutrient concentrations. It should be especially apparent after periods of high wind stress on the water column and nutrient pumping in the coastal zones, when the vertically mixed water column at the inner part of the coastal front can easily restratify. Rapid restratification at the inner side of the frontal zone after storms was shown for the tidal inner front over the eastern Bering Sea shelf (Kachel et al., 2002). Brodeur et al. (1997) show enhanced chlorophyll- $a$ concentrations in a surface layer in the inner part of the coastal front only at when elevated nitrogenous nutrients were observed over the whole coastal domain of St. Paul Island. The data were obtained in mid-September when stratification is particularly important for high phytoplankton productivity because of the seasonal decrease in radiation.

This research showed that the coastal fronts make up rather rigid boundaries for the coastal environment of the islands and limit the exchange between the coastal zones and surrounding middle domain. This is visible in the specific taxonomic composition of phytoplankton in the coastal zones (Table 1) and in the sharp outer borders of the areas which are rich in phytoplankton (Figs. 3 and 4) and planktonic nanoheterotrophs (Fig. 5A and B).

Coastal fronts and closely adjacent areas often feature high concentrations of mesozooplankton, especially in the area to the southwest of St. Paul Island. High concentrations at the coastal fronts were observed for both small-sized and large-sized zooplankton (Hunt et al., 1996; Brodeur et al.,
1997). Our observations showed that the major portion of the high mesozooplankton biomass in the frontal zones was comprised of the herbivorous copepod, Calanus marshallae, which dominates the middle shelf community. This was not the only zooplankton species concentrated in the coastal fronts around the Pribilof Islands: The highest relative biomass values of the planktonic predator Parasagitta elegans, 5 times larger than the values found in the middle and outer shelf domains, were associated with the coastal front near St. Paul Island.

In contrast to other fronts, the shelf partition front (Fig. 1) is specific to the Pribilof area. The front has not been described in prior oceanographic descriptions of the Pribilof area, but its existence can be discerned in some earlier data. Profiles of physical and biological properties presented by Coyle and Cooney (1993) show the presence of a similar front $40-55 \mathrm{~km}$ to the east of St. Paul Island. The front is clearly visible in distributions of salinity in the surface and subthermocline waters, areas of high concentrations of chlorophyll, and high acoustically determined zooplankton biomass. As mentioned before, the formation of the front is most likely due to the flow formed by deep-basin waters penetrating onto the shelf in the Pribilof area and can often be traced to the northeast of St. Paul Island (Stabeno et al., 1999). In the 2 years of this research, the location of the front fluctuated within a distance of $45-60 \mathrm{~km}$ from the island which speaks to its dynamic nature. No specific taxonomic composition of phytoplankton was observed within the frontal zone and closely adjacent areas; rather their high concentrations were comprised of species dominating the middle shelf community during the summer phase of succession. The numbers of phytoplankton found here in June and July were comparable to those in the coastal domains and thus to those reported for the spring bloom time over the shelf (Goering, and Iverson, 1981; Sukhanova et al., 1999). In July 1994 the area of elevated phytoplankton abundance associated with the shelf partition front exhibited enhanced primary production with a value of $207 \mathrm{mg} \mathrm{C} \mathrm{m}^{-3} \mathrm{~d}^{-1}$. In July 1993 an integrated phytoplankton production rate of $4.1 \mathrm{~g} \mathrm{C} \mathrm{m}^{-2} \mathrm{~d}^{-1}$ 
was measured at the eastern side of the frontal zone (Flint et al., 1994; Kopylov et al., 2002). The value is close to the highest phytoplankton production found over the shelf during spring bloom (Starodubtsev, 1970; Goering and Iverson, 1978; Whitledge et al., 1986) and in the coastal domains, coastal fronts and over the shelf break and slope in summer time (Starodubtsev, 1970; Kopylov et al., 2002). The area of high zooplankton biomass was located not in the shelf partition front itself but near its western margin and apart from the phytoplankton peak. Zooplankton biomass in the area reached values of $>2 \mathrm{~g}$ wet weight $\mathrm{m}^{-3}$, comparable to those observed at the shelf break front, and were close to the highest recorded for the eastern Bering Sea shelf.

In the eastern Bering Sea, the shelf break front (Fig. 1) has one with the strongest effects on the quantitative distribution and productivity of plankton (Starodubtsev, 1970; Springer et al., 1996). We found that in the Pribilof area, the high abundance of phytoplankton was attributed not to the shelf break front itself, but to the oceanic domain area adjacent to the front. The location of maximum phytoplankton numbers and biomass at the oceanic side of the shelf break front is not specific for the Pribilof area only. This peak is shown in the data of Goering and Iverson (1981) in the distribution of chlorophyll south of the Pribilof Islands. In summer the numbers and the biomass of phytoplankton at the oceanic side of the shelf break front in some cases reached values associated with the spring bloom period over the shelf, a mean of $2 \times 10^{6}$ cells $1^{-1}$ and $2.5-3.0 \mathrm{~g}$ wet weight $\mathrm{m}^{-3}$ within the upper mixed layer above the seasonal thermocline (Sukhanova et al., 1999). These values were comparable to those we observed at the coastal fronts and coastal domains. The phytoplankton maximum at the oceanic side of the shelf break front, as well as in the coastal domains and coastal fronts, featured high primary production values in summer time compared to those over the outer shelf and in the oceanic domain. The integrated primary production observed in the phytoplankton maximum at the oceanic side of the shelf break front in midJune, $2.5 \mathrm{~g} \mathrm{C} \mathrm{m}^{-2} \mathrm{~d}^{-1}$ (Flint et al., 1996; Kopylov et al., 2002), was close to the $2.3-5.2 \mathrm{~g} \mathrm{C} \mathrm{m}^{-2} \mathrm{~d}^{-1}$ values cited by Goering and Iverson (1978) and Starodubtsev (1970) for the spring bloom period in the area. This indicates that the area adjacent to the shelf break front near the Pribilof Islands featured prolonged high primary production. Measurements done by Starodubtsev, (1970), 3$5 \mathrm{~g} \mathrm{C} \mathrm{m}^{-2} \mathrm{~d}^{-1}$, over the shelf edge to the west of St. Paul Island in July, give supporting evidence. Thus elevated primary production associated with the shelf break front may occur for longer than 2 months after the end of spring bloom.

A peculiarity of the phytoplankton peak associated with the shelf break front was a significant contribution from the same neritic species which dominated the coastal domains and coastal fronts of the Pribilof Islands. This implies that similar conditions for phytoplankton communities exist in these areas during the summer. The most important of these conditions may be the vertical flux of nutrients into the euphotic layer in summer time.

Plankton communities at the outer border of shelf and in the coastal fronts and coastal domains of the Pribilof Islands had an additional similar feature. These areas in summer exhibited the highest abundance of heterotrophic nanoplankton compared with the rest of the shelf and oceanic domain (Fig. 5).

Given a relatively wide shelf area between St. Paul Island and the shelf break, the mesozooplankton maximum was located at the shelf break front or at the oceanic side of the front. It was formed solely by copepod species dominating the oceanic community. Zooplankton peaks with a similar composition and location also were observed in the summer time in the southeastern areas of the Bering Sea shelf having a wide outer domain (Cooney, 1981; Cooney and Coyle, 1982). We found that to the south of St. George Island in the area of a narrow and steep shelf, and a relatively narrow outer domain, the mesozooplankton peaks may be located on either side of the shelf break front. The maximum on the outer side of the front was comprised of oceanic copepod species, but on the inner side it was formed by a 'mixed' community that included both oceanic and shelf species. The maximum biomass produced by the 'mixed' zooplankton 
community reached the highest values known for the Bering Sea at $200 \mathrm{~g}$ wet weight $\mathrm{m}^{-2}$ within 0 $100 \mathrm{~m}$ layer and up to $2.5 \mathrm{~g}$ mean wet weight $\mathrm{m}^{-3}$ in the $20-100 \mathrm{~m}$ layer. If a quantitative estimation of euphausiids, which are a significant fraction of the zooplankton biomass in the shelf break area (up to 27\%-Vidal and Smith, 1986), were included, even higher values would result.

Processes associated with the coastal fronts, coastal domains, shelf partition front, and shelf break front in the Pribilof area result in high biomasses of plankton and make significant contributions to the total biological productivity of this part of the eastern Bering Sea shelf in summer. Their effect on the plankton distributions is always pronounced, though the effect may vary quantitatively in time (Flint et al., 1996). The mechanisms of formation of the high production and concentrations of plankton in the shelf break front area are partially understood (Starodubtsev, 1970; Schumacher and Stabeno, 1994; Springer et al., 1996). In this paper we hypothesized with respect to the mechanisms responsible for the high productivity of the coastal fronts and coastal domains of the Pribilof Islands. It is not yet clear what processes are responsible for the formation of high plankton concentrations and productivity at the shelf partition front and how they are maintained. This will require more comprehensive interdisciplinary studies.

It is evident that the coastal front, shelf partition front, and shelf break front in the Pribilof area may be important foraging sites for organisms at intermediate and upper trophic levels. This is indicated in our data describing the usage of the foraging habitat around the Pribilof Islands by planktivorous sea birds (Flint and Golovkin, 2002) as well as by some observations of the distribution of juvenile pollock (Brodeur et al., 1997) and sea birds (Hunt et al., 1981, 1996; Decker and Hunt, 1996). For sea birds and mammals populating the Pribilof Islands in summer time, the importance of the fronts as foraging grounds may be even greater. The location of a variety of these productive areas at a distance of $10-100 \mathrm{~km}$ from the breeding colonies and rookeries make them easily available during foraging migrations.

\section{Acknowledgements}

We thank the skipper of the $\mathrm{F} / \mathrm{V} H$. Marie II Father George Pletnikoff and the crew of the F/Vs Zolotoi and Ocean Cape (Managing Partner Gordon Blue) for their help and assistance in the field work. Anonymous reviewers provided helpful comments on the earlier version of the manuscript. This research was supported by grants from the US Department of State (S-OPRAQ-93-H-0123), the City of St. Paul (Alaska), and Russian Foundation for Basic Research (98-05-64773, 0005-64414). Partial support for the research was provided to TEW by NSF grants OPP-9617236 and OPP-9819273 and NOAA/SEBSCC grant NA67RJ0147. Contribution number 2665 of the Institute of Marine Science at the University of Alaska Fairbanks.

\section{References}

Brodeur, R.D., Wilson, M.T., Napp, J.M., Stabeno, P.J., Salo, S.A., 1997. Distribution of juvenile pollock relative to frontal structure near the Pribilof Islands, Bering Sea. In: Forage Fishes in Marine Ecosystems. Proceedings of the International Symposium on the Role of Forage Fishes in Marine Ecosystems. University of Alaska Sea Grant, AK-SG-97-01, Fairbanks, pp. 573-589.

Brodeur, R.D., Wilson, M.T., Walters, G.E., Melnikov, I.V., 1999. Forage fish in the Bering Sea: distribution, species associations, and biomass trends. In: Loughlin, T.R., Ohtani, K., (Eds.), Dynamics of the Bering Sea, University of Alaska Sea Grant, AK-SG-99-03, Fairbanks, pp. 509-536.

Caron, D.A., 1983. Technique for enumeration of heterotrophic and phototrophic nanoplankton using epifluorescence microscopy and comparison with other procedures. Applied Environmental Microbiology 46, 491-498.

Chislenko, L.L., 1968. Nomograms for evaluation of weight of aquatic animals by body size and shape. Nauka Publishing, Leningrad, 195 pp.

Coachman, L.K., 1986. Circulation, water masses, and fluxes on the southeastern Bering Sea shelf. Continental Shelf Research 5, 23-108.

Cooney, R.T., 1981. Bering Sea zooplankton and micronekton communities with emphasis on annual production. In: Hood, D.W., Calder, J.A. (Eds.), The Eastern Bering Sea Shelf: Oceanography and Resources, Vol. 2. University of Washington Press, Seattle, pp. 947-974.

Cooney, R.T., Coyle, K.O., 1982. Trophic implication of crossshelf copepod distributions in the southeastern Bering Sea. Marine Biology 70, 187-196. 
Coyle, K.O., Cooney, R.T., 1993. Water column sound scattering and hydrography around the Pribilof Islands. Continental Shelf Research 13, 803-827.

Daly, K.L., Smith Jr., W.O., 1993. Physical-biological interactions influencing marine plankton production. Annual Review Ecological Systems 24, 555-585.

Decker, M.B., Hunt Jr., G.L., 1996. Foraging by murres (Uria spp.) at tidal fronts surrounding the Pribilof Islands, Alaska, USA. Marine Ecology Progress Series 139, 1-10.

Fedorov, K.N., 1983. Physical Nature and Structure of Oceanic Fronts. Hydrometizdat, Leningrad, 296 pp.

Flint, M.V., Golovkin, A.N., 2002. How do small planktivorous auks (Least Auklets) use foraging habitat around breeding colonies? Adaptation to mesoscale distributions of forage zooplankton. Oceanology, in press.

Flint, M.V., Kolosova, E.G., 1990. Mesoplankton of Peruvian coastal waters. In: Vinogradov, M.E., Musaeva, E.I. (Eds.), Ecosystems of the Eastern Boundary Currents and Central Regions of the Pacific Ocean. Nauka Publishing, Moscow, pp. 213-229.

Flint, M.V., Drits, A.V., Emelianov, M.V., Golovkin, A.N., Haney, J.C., Merculieff, I., Nalbandov, Y.R., Poyarkov, S.G., Rybnikov, P.V., Sukhanova, I.N., Whitledge, T.E., Zubkov, M.V., 1994. Investigations of the Pribilof marine ecosystem, second year: study of marine ecosystem in the vicinity of the Pribilof Islands for general ecological evaluation and elucidation of the most valuable ecological zones. Project Report. P.P. Shirshov Inst. Oceanol., Moscow, 504 pp.

Flint, M.V., Drits, A.V., Emelianov, M.V., Kopylov, A.I., Merculieff, I., Poyarkov, S.G., Rybnikov, P.V., Sukhanova, I.N., Whitledge, T.E., 1996. Investigations of the Pribilof marine ecosystem, third year: significance of oceanographic and biological processes in the outer and middle shelf domains, at the shelf break and middle fronts for biological productivity of the Pribilof ecosystem, the eastern Bering Sea. Oceanographic conditions and plankton communities in the coastal zones and coastal fronts of the St. Paul and St. George Islands. Project Report. P.P. Shirshov Inst. Oceanol., Moscow, 407 pp.

Franks, P.J.S., Chen, C., 1996. Plankton production in tidal fronts: a model of Georges Banks in the summer. Journal of Marine Research 54, 631-651.

Goering, J.J., Iverson, R.L., 1978. PROBES Phase 1 Progress Report 1977-1978. Institute of Marine Science, University of Alaska Fairbanks, Fairbanks, 488 p.

Goering, J.J., Iverson, R.L., 1981. Phytoplankton distribution on the southeastern Bering Sea shelf. In: Hood, D.W., Calder, J.A. (Eds.), The Eastern Bering Sea Shelf: Oceanography and Resources, Vol. 2. University of Washington Press, Seattle, pp. 933-946.

Gruzov, L.N., Alekseeva, L.G., 1971. On relation of body weight and length in the main groups of zooplankton in the equatorial Atlantic. Trudi AtlantNIRO 37, 378-400.

Hickey, J.J., Craighead, F.L., 1977. A census of seabirds on the Pribilof Islands. Environmental assessment of the Alaska continental shelf. Annual Reports of Principal Investiga- tors, NOAA Environmental Research Laboratory, Boulder, Colorado, pp. 96-125.

Hunt Jr., G.L., Eppley, Z., Burgeston, B., Squibb, R., 1981. Reproductive ecology, foods, and forage areas of seabirds nesting on the Pribilof Islands, 1975-1979. Environmental assessment of the Alaskan continental shelf. Final reports of principal investigators, Vol. 12. NOAA/OMPA, Washington, DC, pp. 1-257.

Hunt Jr., G.L., Coyle, K.O., Hoffman, S., Decker, M.B., Flint, E.N., 1996. Foraging ecology of short-tailed shearwaters near the Pribilof Islands, Bering Sea. Marine Ecology Progress Series 141, 1-11.

Ivanov, B.G., 1964. Some results of the investigations on the biology and distribution of shrimp in the Pribilof area of the Bering Sea. In: Moiseev, P.A. (Ed.), Soviet Fisheries Investigations in the North-Eastern Part of the Pacific Ocean, Part II. VNIRO Proceeding Vol. 49 and TINRO Proceedings Vol. 51. Pischevaya Promishlennost, Moscow, pp. 113-122.

Iverson, R.L., Coachman, L.K., Cooney, R.T., English, T.S., Goering, J.J., Hunt Jr., G.L., Macauley, M.C., McRoy, C.P., Reeburg, W.S., Whitledge, T.E., 1979. Ecological significance of fronts in the southeastern Bering Sea. In: Livingston, R.J. (Ed.), Ecological Processes in Coastal and Marine Ecosystems. Plenum Press, New York, London, pp. 437-466.

Kachel, N.B., Hunt Jr., G.L., Salo, S.A., Schumacher, J.D., Stabeno, P.J., Whitledge, T.E., 2002. Characteristics and variability of the inner front of the southeastern Bering Sea. Deep-Sea Research II, this issue (PII: S0967-0645(02) 00324-7)

Kinder, T.H., Coachman, L.K., 1978. The front overlying the continental slope in the eastern Bering Sea. Journal of Geophysical Research 83, 4551-4559.

Kinder, T.H., Schumacher, J.D., 1981. Hydrographic structure over the continental shelf of the southeastern Bering Sea. In: Hood, D.W., Calder, J.A. (Eds.), The Eastern Bering Sea Shelf: Oceanography and Resources, Vol. 1. University of Washington Press, Seattle, pp. 31-52.

Kinder, T.H., Hunt Jr., G.L., Schneider, D.C., Schumacher, J.D., 1983. Correlation between seabirds and oceanic fronts around the Pribilof Islands, Alaska. Estuarine Coastal Shelf Science 16, 309-319.

Kopylov, A.I., Flint, M.V., Drits, A.V., 2002. Phytoplankton primary production in the eastern part of the Bering Sea. Oceanology 42, 215-225, Translated from Okeanologiya 42, 228-239.

Kowalik, Z., 1999. Bering Sea Tides. In: Loughlin, T.R., Ohtani, K. (Eds.), Dynamics of the Bering Sea. University of Alaska Sea Grant, Fairbanks, pp. 93-128.

Le Fevre, J., 1986. Aspects of the biology of frontal systems. Advances in Marine Biology 23, 163-299.

MacIntosh, R.A., Somerton, D.A., 1981. Large marine gastropods of the eastern Bering Sea. In: Hood, D.W., Calder, J.A. (Eds.), The Eastern Bering Sea Shelf: Oceanography and Resources, Vol. 2. University of Washington Press, Seattle, pp. 1215-1228. 
Motoda, S., Minoda, T., 1974. Plankton of the Bering Sea. In: Hood, D.W., Kelley, E.J. (Eds.), Oceanography of the Bering Sea with Emphasis on Renewable Resources, Occasional Publication No. 2, Institute of Marine Science. University of Alaska, Fairbanks, pp. 207-410.

Onoda, M., Nagai, N., Toishi, S., Yoshida, K., Baba, N., 1986. Estimation of pollock biomass in the sea near the Pribilof Islands in the Bering Sea in July 1985. Far-east Seas Fisheries Research Laboratory, Shimizu, 18 pp.

Porter, K.G., Feig, Y.S., 1980. The use of DAPI for identifying and counting of aquatic microflora. Limnology and Oceanography 25, 943-948.

Poyarkov, S.G., 2000. Mesoscale frontal structure in the Pribilof region of the eastern Bering Sea shelf. In: Oceanic Fronts and Related Phenomena, Konstantin Fedorov Memorial International Symposium Proceedings. UNESCO Workshop Series No. 159, UNESCO, Paris, pp. 446-454.

Poyarkov, S.G., 2001. The peculiarities of thermohaline structure and mesoscale variability of the St. Paul Island coastal front (Pribilof Islands, Bering Sea). Oceanology 41, 14-20.

Poyarkov, S.G., Emelianov, M.V., 2000. Peculiarities of the thermohaline structure and variability of the St. Paul Island coastal front (the Bering Sea). In: Oceanic Fronts and Related Phenomena, Konstantin Fedorov Memorial International Symposium Proceedings. UNESCO Workshop Series No. 159, UNESCO, Paris, pp. 439-445.

Schneider, D.C., Harrison, N.M., Hunt Jr., G.L., 1990. Seabird diet at a front near the Pribilof Islands, Alaska. Studies in Avian Biology 14, 61-66.

Schumacher, J.D., Reed, R.K., 1993. Circulation and crossshelf transport and exchange along the Bering Sea continental shelf edge. Pacific Marine Environmental Laboratory, Seattle, $32 \mathrm{pp}$.

Schumacher, J.D., Stabeno, P.J., 1994. Ubiquitous eddies of the eastern Bering Sea and their coincidence with concentrations of larval pollock. Fisheries Oceanography 3, 182-190.

Schumacher, J.D., Kinder, T.H., Pashinski, D.J., Charnell, R.I., 1979. A structural front over the continental shelf of the eastern Bering Sea. Journal of Physical Oceanography 9, 79-87.

Sorokin, Yu.I., 1973. Primary production of the seas and oceans. In: General Ecology, Biocenology, Hydrobiology: Biological Productivity of Water Bodies, Vol. 1. VINITI, Moscow, pp. 7-46 (in Russian).
Sowls, A.L., Hatch, S.A., Lensink, C.J., 1978. Catalog of Alaskan seabird colonies. US Fish and Wildlife Series, FWS/OBS-78/78, Washington, DC, 350 pp.

Springer, A.M., McRoy, C.P., Flint, M.V., 1996. The Bering Sea green belt: shelf age processes and ecosystem production. Fisheries Oceanography 5, 205-223.

Stabeno, P.J., Schumacher, J.D., Salo, S.A., Hunt Jr., G.L., Flint, M.V., 1999. Physical environment around the Pribilof Islands. In: Loughlin, T.R., Ohtani, K. (Eds.), Dynamics of the Bering Sea. University of Alaska Sea Grant, Fairbanks, pp. 193-215.

Starodubtsev, E.G., 1970. Seasonal changes in primary production in the southeastern Bering Sea. In: Moiseev, P.A. (Ed.), Soviet Fisheries Investigations in the NorthEastern Part of the Pacific Ocean, Part V., VNIRO Proceeding Vol. 70 and TINRO Proceedings Vol. 72. Pischevaya Promishlennost, Moscow, pp. 87-91.

Sukhanova, I.N., 1983. Concentrating of phytoplankton in a sample. In: Vinogradov, M.E. (Ed.) Contemporary Methods of Quantitative Estimation of Marine Plankton Distribution. Nauka Publishing, Moscow, pp. 97-104.

Sukhanova, I.N., Semina, H.I., Ventsel, M.V., 1999. Spatial distribution and temporal variability of phytoplankton in the Bering Sea. In: Loughlin, T.R., Ohtani, K. (Eds.), Dynamics of the Bering Sea. University of Alaska Sea Grant, Fairbanks, pp. 453-483.

Traynor, J.T., Smith, D., 1996. Summer distribution and abundance of age- 0 walleye pollock, Theragra chalcogram$m a$, in the Bering Sea. In: Brodeur, R.D., Livingston, P.A., Loughlin, T.R., Hollowed, A.B. (Eds.), Ecology of Juvenile Walleye Pollock, Theragra chalcogramma, NOAA Technical Report, NMFS 126, pp. 57-59.

Vidal, J., Smith, S.L., 1986. Biomass, growth and development of populations of herbivorous zooplankton in the southeastern Bering Sea. Deep-Sea Research I 33, 523-556.

Whitledge, T.E., Reeburch, W.S., Walsh, J.J., 1986. Seasonal inorganic nitrogen distributions and dynamics in the southeastern Bering Sea. Continental Shelf Research 5, 109-132.

York, A.E., 1987. Northern fur seal, Callorhinus ursinus, eastern Pacific population (Pribilof Islands, Alaska, and San Miguel Island, California). In: Croxall, J.P., Genry, R.L. (Eds.), Status, Biology and Ecology of Fur Seals, NOAA Technical Report NMFS 51, pp. 17-21. 